\title{
BROKER-DEALER SELLING PRACTICE STANDARDS: THE IMPORTANCE OF ADMINISTRATIVE ADJUDICATION IN THEIR DEVELOPMENT*
}

\author{
Manuel, F. Cohen† and Joel J. Rabin $\ddagger$
}

The debate on the merits of the administrative process continues, but the issues seem to have changed. Earlier critics charged that the agencies were unconstitutional bodies and that their basic programs infringed individual rights. ${ }^{1}$ In recent years, the agencies have been assailed on the grounds that their procedures are unfair and inefficient ${ }^{2}$ and that they are not adequately performing the tasks with which they are vested. ${ }^{3}$ There seems to be less criticism of the concept and more concern with methods, with the result that most recent administrative reforms have been designed to improve the procedures of individual agencies. ${ }^{4}$ On a broader scale, the Congress is currently considering bills which would substantially amend the Administrative Procedure Act, ${ }^{5}$ and establish a permanent Administrative Conference of the United States to study continuously and to advise on agency procedure. ${ }^{6}$

Not all students of the administrative process have been as critical. A number have suggested that the agencies generally perform their tasks well, or at least as effectively as other governmental bodies. ${ }^{7}$ They point out that much of the criticism has not been substantiated and that there is a need for study and evaluation of

- This article carries a date of authorship of May 15, 1964. The Securities and Exchange Commission, as a matter of policy, disclaims responsibility for any private publication by any of its members or employees. The views expressed here are those of the authors and do not necessarily reflect the views of the Commission or its staff.

†B.S. I933, Brooklyn College; LL.B. 1936, Brooklyn Law School. Member of the Securities and Exchange Commission.

$\ddagger$ B.S. 1957, LL.B. I96r, University of Wisconsin. Legal Assistant to Mr. Cohen.

${ }^{I}$ See I Kenneth C. Davis, Administrative Law Treatise \$ 1.04 (r958) [hereinafter cited as Davis].

${ }^{3}$ E.g., Hector, Problems of the CAB and the Independent Regulatory Commissions, 69 YALE L.J. $93 \mathrm{I}$ (1960) (originally prepared as a memorandum from Louis J. Hector to the President, Sept. 10, 1959); Miller, The Advocate Before Administrative Agencies, 1956 U. IL.. L.F. I89.

${ }^{B}$ E.g., James M. Landis, Report on Regulatory Agencies to the President-Elect (ig6o) (also printed in pamphlet form as a committee print of the Senate Judiciary Committee, 86th Cong., 2d Sess. (1960)); Emmette S. Redford, National Regulatory Commissions-Need for A New Look (I959).

'In the past few years, the problem of inefficiency has been attacked by reorganization plans and new statutes which permit agencies greater flexibility and authority in the delegation of functions in many areas of agency responsibility. E.g., Reorganization Plan No. 3 of 196r, 26 Fed. Reg. 5989, 75 Stat. 837 (I96I) (CAB reorganization plan); 76 Stat. 394 (1962), r5 U.S.C. $\$ 78 d-1$ (Supp. IV, r963) (SEC delegation of functions statute).

60 Stat. 237-44 (1946), 5 U.S.C. $\$ \$$ roor-II (1958). The bill proposing ameadments to the act is $S .166_{3}, 88$ th Cong., Ist Sess. (1963).

' S. 1664, H.R. 7200, 88th Cong., Ist Sess. (1963).

${ }^{7}$ E.g., Fick, Issues and Accomplishments in Administrative Regulation: Some Polisical Aspects, 26 LAw \& Contemp. Prob. 283, 306 (I96I); Kintner, The Current Ordeal of the Administrative Process: In Reply to Mr. Hector, 69 YALE L.J. 965 (1960); Gardner, The Administrative Process, in LEgar INstrTuTIONS TOdaY and ToMorrow I08 (Columbia University Law School, r959). 
the performance of each agency. ${ }^{8}$ The Ig6I-Ig62 Administrative Conference stimulated excellent studies along these lines. ${ }^{9}$

This paper will discuss a limited aspect of the operations of the Securities and Exchange. Commission (SEC) in relation to two themes of the current criticism: (I) the charge that policy development and enunciation by the agencies is inadequate, and particularly that agencies rely too much on adjudication and the ad hoc approach at the expense of formal rule-making; and (2) the continuing concern with the combination in most agencies of adjudicatory and other functions. The following sections elaborate on the nature of these themes and discuss the Commission's development of standards for broker-dealers and their salesmen in the sale of securities and the Commission's internal rules and procedures in the adjudication of cases in relation to them. Finally, some general thoughts on the administrative process are offered.

The discussion of Commission rules, cases, and statements of policy is not meant to be comprehensive nor is any attempt made to analyze them in depth; that task has been undertaken by others. ${ }^{10}$ Instead, this paper is meant to illustrate how these devices have been used to develop and enunciate policy in one area of the Commission's responsibilities. At the outset, it seems necessary, albeit immodest, to point out that the Commission has generally fared well in most evaluations of agency performance and its operations have received significant praise. ${ }^{11}$ This paper, therefore, tests criticisms of the administrative process against an agency considered to be fairly effective.

\section{Criticism of the Use of Adjudication for Policy Formation}

The term adjudication as used here and throughout the paper is meant to include all those proceedings in which agencies develop an evidentiary record in hearings and provide opportunities for briefs and oral arguments to decide controversies affecting particular parties, whether or not they fall technically within the definition

'See Bernstein, The Regulatory Process: A Framework for Analysis, 26 LAw \& Contemp. Pron. 329 (I96I).

${ }^{\circ}$ See Selected Reports of the Administrative Conference of the United States, S. Doc. No. 24, 88th Cong., Ist'Sess. (1963); Auerbach, The Federal Trade Commission: Internal Organization and Procedure, 48 Min. L. REv. 383 ( 1964 ).

${ }^{10}$ Louis Loss, Securities Regulation 1421-45, 1474-1518 (2d ed. 1961) [hereinafter cited as Loss]; Lesh, Federal Regulation of Over-the-Counter Brokers and Dealers in Securities, 59 Harv. L. REv. 1237 (1946). Reference was also made to the manuscript of a comprehensive work, tentatively entitled "Registration and Regulation of Brokers and Dealers," by Mr. Ezra Weiss, which will be published in the near future by the Bureau of National Affairs.

${ }^{11}$ Jaffe, The Effective Limits of the Administrative Process: A Reevaluation, 67 Harv. L. REv. I105, (1954); Task Force Report on Regulatory Commissions, Commission on Organization of tire Executive Brakci of thiE Governacent I44 (I949). It should also be noted that the Commission has been the recipient of censure. Report of Special Study of Securities Markets of the Securities and Exchange Commission, H.R. Doc. No. 95, 88th Cong., Ist Sess., pt. 4, at 692-728 (1963) [hereinafter cited as Special Study]; Landis, op. cit. supra note 3, at 45-48. Cf. Barron's, "Guilty Until Proven Innocent," Feb. 3, ro, and 17, 1964, pp. 1, 3, and 3, respectively; and Barron's, "Who Watches the Watchdogs?," Jan. I4, 1963, p. 3 . 
of adjudication in the Administrative Procedure Act. ${ }^{12}$ Some of those who criticize agency reliance on adjudication to develop standards stress that it is an inefficient and inadequate method for proper policy development. They point to the accidental nature of individual cases, the problems caused by inadequate records, and the slowness of the process; ${ }^{13}$ and they say that the technical legal restrictions surrounding agency adjudication prevent the use of other flexible procedures which could be used in the search for the best method of solving particular problems. ${ }^{14}$

Other critics do not make such a frontal assault on adjudication as a method for policy formulation. They concede its value, but contend that some agencies rely on adjudication almost to the exclusion of alternatives, such as formal rule-making and publication of statements of policy, which may be more appropriate for the development of certain standards. ${ }^{15}$ This point of view recognizes that the flexibility possessed by the courts in developing common law policies and rules is at least of equal importance in the administrative process. The principal concern expressed by these critics seems to relate to the need for clear policy formulation regardless of which method is used.

One of the most articulate and persuasive exponents of this second view is Judge Henry J. Friendly of the United States Court of Appeals for the Second Circuit. Judge Friendly believes that the failure to define standards more specifically, to "make law" within the confines of the statutory charter, is the basic deficiency of agency performance and that, if this fault is corrected, the other ills of the administrative process will also be cured. ${ }^{16} \mathrm{He}$ believes that the executive and legislative branches of government and teachers and students of the law can aid in reaching this goal, but that the first and main responsibility lies with the agencies themselves. ${ }^{17}$ In performing this task, the agencies need not abandon the case-by-case method, even if they could.

Judge Friendly feels, however, that statements of policy and formal rules have certain advantages over adjudication for defining standards, since they make possible the avoidance of the trivia and personalities involved in individual cases and permit agency members to concentrate on the principles involved. ${ }^{18}$ He suggests that the development of a policy statement educates the agency members in the work of the

${ }^{19}$ Administrative Procedure Act $\$ 2,60$ Stat. 237 (1946), as amended, 5 U.S.C. $\$$ I0or (1958).

19 Hector, supra note 2, at 932-38; Board of Investigation and Research, Report on Practices and Procedures of Government Controls, H.R. Doc. No. 678, 78th Cong., 2d Sess. 80-83 (1944).

It McFarland, Landis Report: The Voice of One Crying in the Wilderness, 47 VA. L. REv. 373, 433 (196r); LAndis, op. cit. supra note 3, at I8-ig.

${ }^{18}$ Henry J. Friendly, The Federal Administrative Agencies-The NeEd for Better Definition of' STANDARDs I43-45 (1962) [hereinafter cited as FrIendLY]. (This is the published form of the Oliver Wendell Holmes Lectures which Judge Friendly delivered at Harvard Law School in February 1962.) Bernstein, supra note 8, at 332. See also Baker, Policy by Rule or Ad Hoc Approach-Which Should It Be?, 22 LAw AND CONTEMP. PROB. 658. (I957). for. a general comparison. of the advantages of the two methods.

${ }^{36}$ FrIENDLY vii.

${ }^{17} 1 d$. at 142.

- ${ }^{18}$ Id. at I 45-47. 
agency and is likely to be the product of much unavoidable effort and thought. ${ }^{1 !}$ This device also avoids the usual retroactive effect of case decisions, although rules announced in cases can be limited to future effectiveness. Formal rules, he believes, have most of the same advantages; but in areas where specific rule-making power has not been granted, formal rules may be susceptible to attack from courts as unconstitutional legislation by the agencies. Agencies may also prefer statements of policy when the principle involved is not suitable, or not ready, for the precise articulation required in a rule.

That agencies are not limited to formal rule-making and that they may develop rules by administrative adjudication in particular cases has been settled at least since the Supreme Court decided the two Chenery cases. ${ }^{20}$ In the second case the Court upheld the use by the SEC of an administrative proceeding to enunciate a new interpretation of a provision of the Public Utility Holding Company Act of $1935 .^{21}$ The Court suggested, however, that since agencies, unlike courts, had formal, substantive rule-making powers, they should develop standards, to the extent possible, through "this quasi-legislative promulgation of rules to be applied in the future."22 Nevertheless, it was recognized that three reasons exist for retention by agencies of the power to develop standards in cases: unforeseen problems may arise, the agency may not have sufficient experience to draft a general rule, or the problem may be so specialized that it cannot be encompassed within the terms of a general rule. ${ }^{23}$ The Court held that the choice between developing policy by general rules or by adjudicatory proceedings "lies primarily in the informed discretion of the administrative agency."24 Thus, agencies are not limited to formal rule-making; policy considerations may determine the most appropriate method to be used.

\section{Development of Standards on Selling Practices}

\section{A. Brief Background and Statutory Framework}

At the outset, some points concerning the general significance of federal regulation of selling practices deserve emphasis and a brief outline of the statutes may be helpful. The federal securities acts were enacted because the common law remedies and state criminal and blue-sky laws had proved ineffective in preventing abuses in the sale and trading of securities. This failure resulted to a large extent from the geographic limitations of state enforcement activities. ${ }^{25}$ However, it is clear that, in enacting the securities laws, . Congress intended to raise the standards of conduct of those playing important roles in the securities markets as well as to provide a

\footnotetext{
${ }^{10}$ At least one of the authors could not restrain a sigh at this impeachment, albeit mild, of the competence and industry of agency members.

${ }^{30}$ SEC v. Cheriery Corp., 332 U.S. 194 (1947); SEC v. Chenery Corp., 318 U.S. 80 (1943).

${ }^{21}$ Federal Water Service Corp., 18 S.E.C. 231 (1945).

22 SEC v. Chenery Corp., 332 U.S. 194, 202 (1947).

${ }^{23}$ Id. at 202-03.

24 Id. at 203 .

${ }^{25}$ I Loss 105. For a thorough discussion of the factors leading to the enactment of the federal securities acts, see I Loss 105-28.
} 
national enforcement scheme. In his message to Congress accompanying the bill which became the Securities Act of 1933, President Roosevelt said: "This proposal adds to the ancient rule of caveat emptor, the further doctrine 'let the seller also beware." "26 The preamble to the Securities Exchange Act of 1934 states that one of its purposes is "to prevent inequitable and unfair practices" on exchanges and in the over-the-counter markets. 27 The courts have agreed that the provisions of the statutes dealing with selling practices impose a higher standard of conduct than the common law action of deceit which is their main antecedent. ${ }^{28}$

But Congress did not pre-empt the regulatory field. ${ }^{2 \theta}$ Thus the common law remedies and state statutes still operate and federal regulation is only one of several layers of control over broker-dealer conduct. In addition, controls are exercised by the self-regulatory organizations-the National Association of Securities Dealers (NASD) and the stock exchanges-under wide charters such as "high standards of commercial honor" and "just and equitable principles of trade" (NASD) and "principles of good business practice" (New York Stock Exchange). ${ }^{30}$ The preoccupation of the following discussion with the activities of the SEC should not be taken to mean that the activities of the state agencies and the self-regulatory bodies have not been important. The efforts of state securities officials, the NASD, and the major exchanges constitute significant parts of the total regulation of the securities industry, ${ }^{31}$ and, as more states enact the Uniform Securities $\mathrm{Act}^{32}$ and the selfregulatory organizations strengthen their enforcement programs, ${ }^{33}$ the importance of their activities is likely to increase. Nevertheless, regulation by the SEC, because of the wider scope of its authority and its special powers over and relationships to the self-regulatory bodies, has been and probably will continue to be the major focus of control over the securities industry.

Direct Commission control over selling practices is based largely on the Securities

${ }^{30}$ S. Rep. No. 47 at 6 and H.R. Rep. No. 85 at 2, 73 d Cong., rst Sess. (1933).

${ }^{37} 4^{8}$ Stat. 88I (r934).

${ }^{28} 3$ Loss $1435-42$ and cases cited therein.

${ }^{20}$ Securities Act of $1933 \S x 8,48$ Stat. 85 (1933), I5 U.S.C. $\$ 77 \mathrm{r}$ (1958); Securities Exchange Act of $1934 \S 28(\mathrm{a}), 48$ Stat. 903 (1934), I5 U.S.C. $\$ 78 \mathrm{bb}$ (a) (1958).

${ }^{8}$ Rules of Fair Practice, art. III, § I, NASD MANUAL D-5; Rule 40I, 2 NEw YoRk STOck Exchange Guide $\$ 2401$. For a thorough discussion of the activities of the self-regulatory bodies and the relationship of their activities to the Commission's, see chapter XII of the Special Study. The self-regulatory organizations exercise essentially governmental powers under the Commission's oversight, and the Special Study recommended that this system be strengthened and continued. Strangely, not much attention has been given to this joint effort of a government agency and private bodies by scholars and critics of the administrative process or to an evaluation of this cooperative scheme and as to possibilities of application elsewhere. One article dealing with this subject is contained in this symposium. See Jennings, Self-Regulation in the Securities Industry: The Role of the Securities and Exchange Commission, 29 Law \& Contemp. Prob. $66_{3}$ (1964).

s2 Special Study, pt. 4, at 501-02, 734-37.

${ }^{32}$ Seventeen states have already adopted the Uniform Securities Act in whole or substantially. BLoE SkY L. REP. If 4901 (1963).

${ }^{20}$ As noted in chapter XII of the Special Study, the NASD, the New York Stock Exchange, and the American Stock Exchange have taken steps to improve their enforcement programs; their efforts in this regard are continuing. 
Act of $1933^{34}$ and the Securities Exchange Act of $19340^{35}$ The 1933 Act is primarily directed at the public offering of new issues of securities. It adopted the disclosure principle of the English Companies Act ${ }^{38}$ to deal with abuses in this area, that is, a requirement of adequate and accurate written information-including a prospectusin all offerings subject to the statute. Supplementing this prospectus requirement, section $I 7$ of the 1933 Act prohibits fraudulent practices and false and misleading written or oral statements in the offer or sale of securities. The 1934 Act is a regulatory statute in a more conventional sense. It extends the disclosure principle to securities traded on the stock exchanges, prohibits specific trading practices, sets general standards of conduct for broker-dealers, authorizes the Commission to adopt rules governing broker-dealer conduct, and prescribes a licensing (and revocation) procedure for broker-dealers. Finally, it provides the self-regulatory authorities with certain governmental powers and vests in the Commission oversight and review responsibilities. Both acts impose civil and criminal liabilities for violations of their provisions.

Although the Exchange Act contains specific prohibitions and precise regulatory mandates with respect to certain broker-dealer activities, ${ }^{37}$ the Commission's broadest powers with respect to broker-dealer conduct are based on those provisions which prescribe a general standard of conduct to be observed in all securities transactions. These are found in sections $10(b), 1_{5}(c)(r)$, and $1_{5}(c)(2)$, which, with some differences, prohibit the use of "manipulative, deceptive, or other fraudulent device or contrivance." Section ro(b) applies to purchases and sales by any person, and sections ${ }_{15}(\mathrm{c})(\mathrm{I})$ and ${ }_{15}(\mathrm{c})(2)$ apply to transactions by broker-dealers. In addition to the general rule-making powers in both acts authorizing the Commission to adopt rules necessary to enforcement of these acts, ${ }^{38}$ these sections vest in the Commission specific authority to define "manipulative, deceptive, or otherwise fraudulent" devices, contrivances, acts, and practices, and to promulgate rules designed to prevent such activities. Under other provisions of the act, the Commission has established reporting requirements and rules with respect to record-keeping, ${ }^{89}$ financial responsibility, ${ }^{40}$ and the hypothecation of customer's securities. ${ }^{41}$

The licensing requirement for broker-dealers in section ${ }_{15}(\mathrm{~b})$ of the Exchange Act requires that all broker-dealers who engage in securities transactions by use of

${ }^{84}{ }_{4} 8$ Stat. 74 (1933), as amended, 15 U.S.C. $\$ 577 a-a 2$ (1958), as amended, 15 U.S.C. $\$ \$ 77 b-h$ (Supp. IV, .x963) [hereinafter cited as Securities Act].

${ }^{88} 48$ Stat. 881 (I934), as amended, I5 U.S.C. $\$ \$ 78 \mathrm{a}$ to hh-l. (1958), as amended, I5 U.S.C. $\$ 578 \mathrm{c}-\mathrm{s}$ (Supp. IV, 1963) [hereinafter cited as Exchange Act].

so I \& 12 Geo. 6, c. 38, consolidating Companies Act, 1929, 19 \& 20 Geo. 5, c. 23, and Companics Act, 1947, Io \& ix Geo. 6, c. 47. The 1929 Act was one of the models used for the Securities, Act.

${ }^{87}$ E.g., Exchange Act $\$ \$ 8,9$, 10(a) and $1 x$.

${ }^{83}$ Securities Act $\$ 19(a)$; Exchange Act $\$ 23(a)$.

${ }^{39}$ Exchange Act $\$ 17$, and SEC Rules $x 7^{a-2}$ to -7, I7 C.F.R. $240.17 a-2$ to -7 , thereunder [hereinafter only the SEC Rules citations will be given for rules under the Exchange Act, since they are all in 17 C.F.R. under section 240 with their numbers unchanged].

" 10 Exchange Act $\$$ is (c) (3) and Rule 15c3-r", thereunder.

${ }^{41}$ Exchange Act $\$ \$ 8(c)(x)$ and $15(c)(2)$ and Rules $8 c-1$ and $x_{5}(2-x$, thereunder. 
federal jurisdictional means ${ }^{42}$ (otherwise than on a national securities exchange), except those doing an exclusively intrastate business, must register with the Commission. ${ }^{43}$ Since most exchange member firms do some over-the-counter business, this provision has required practically all broker-dealers doing some interstate business to register under the act. ${ }^{44}$ The Commission is empowered to deny or to revoke registration if a broker-dealer or his salesman has wilfully violated any provision of the I934 Act or the 1933 Act or any rule under these statutes. ${ }^{45}$ The effect of revocation is to prevent a broker-dealer from engaging in the securities business as a salesman, or as a broker-dealer, without prior Commission approval. Where it appears that a violation has occurred, the Commission has available to it several alternatives which it can pursue singly or in combination. It may seek an injunction against continuance of such conduct ${ }^{46}$ or a criminal conviction, ${ }^{47}$ or it may institute an administrative proceeding as a basis for a formal determination whether a violation has in fact occurred and whether the broker-dealer registration should be revoked or an application for registration denied. ${ }^{48}$ The method which the Commission uses in a particular case depends on urgency, equity, ${ }^{49}$ nature of the alleged violations involved and a variety of other considerations.

Court decisions dealing with provisions of the securities acts, particularly the more recent ones, have contributed significantly to the articulation of standards for broker-dealer selling practices. However, these have not been as numerous as Commission formal rules, administrative decisions, and statements of policy in this area. Only summary statements of some of the decisions of the NASD and the

"Section 15(2) of the Exchange Act provides that no broker-dealer "shall make use of the mails or of any means or instrumentality of interstate commerce" to engage in securities transactions unless he is registered under $\$ 15(b)$, which requires registration with the Commission.

"As part of its current legislative program now before the Congress, the Commission has proposed the elimination of this intrastate exemption.

It should be noted that the fraud provisions of $\S 15(c)$ and $\S 10(b)$ apply to unregistered brokerdealers doing an exclusively intrastate business so long as the jurisdictional means are used. This coverage is similar to that under the anti-fraud provision of the Securities Act, $\$ 17(a)$, which applies with equal force to securities exempt from the registration requirements of that act.

"The Special Study estimated that there were more than 6,000 broker-dealer firms in the country. On February 28, 1962, 5,785 of these firms were registered with the Commission. Special Study, pt. I, x6.

${ }^{15}$ Exchange Act $\oint 15(\mathrm{~b})$.

${ }^{16}$ Exchange Act $\$ 2 \mathrm{I}(\mathrm{e})$.

"Exchange Act $\$ 32(a)$. Recommendations for criminal proceedings for violations of the securities acts are presented by the Commission to the Department of Justice. Such proceedings are prosecuted by the United States Attorney for the federal judicial distriet in which the action is to be brought.

${ }^{48}$ Exchange Act $\$ 15(b)$.

${ }^{40}$ To revoke the registration of a broker-dealer, the Commission must find that such revocation is in the "public interest" and that the broker-dealer firm or a person affiliated with it has violated the securities acts or committed one of the other specific acts which provide a basis for revocation of registration. Exchange Act $\$ 15(b)$.

Section 19 (a) (3) of the Exchange Act gives the Commission the power to suspend or expel officers or members of exchanges for violating any provision of the I934 Act or rule thereunder. About 30 adjudicatory proceedings against exchange members have been brought under this section, of which about half were also directed at the firms' registrations as over-the-counter 'broker-dealers under 15 (b). See 2 Loss I172-75. 
exchanges in disciplinary proceedings are published. ${ }^{50}$ Consequently, standards for selling practices have been most fully developed and articulated in Commission materials and our discussion will concentrate on them.

\section{B. Commission's Use of Formal Rules}

It was a deliberate decision to vest in the Commission the broad rule-making powers in regard to selling practices found in the Exchange Act. ${ }^{61}$ The bill which became the act originally dealt very specifically with a number of practices which had given rise to abuse. Representatives of the securities industry argued that these provisions lacked the flexibility necessary to deal with such complicated matters and that unforeseen developments might easily create the need for statutory revision. Accordingly, the statute, as enacted in 1934, gave the Commission wide discretion as to the form of rules to implement the statutory purposes in the over-the-counter market. ${ }^{62}$ This discretion was limited by the amendments enacted in 1936, without significantly affecting the Commission's rule-making powers over selling practices. ${ }^{\text {t3 }}$

By 1937 the Commission had adopted eleven rules concerned with a variety of broker-dealer selling practices. ${ }^{54}$ These were based in part on the fair practice rules drafted by the Investment Bankers Code Committee which had been created under the National Industrial Recovery Act and on state blue-sky regulations. ${ }^{55}$ Thereafter, the pace slackened; through I944 only four new rules were adopted." The next rule was promulgated in 1954; it concerns a problem not related to fraudulent conduct of the usual variety. ${ }^{57}$ In 1955 , the three rules dealing with trading in a security by a broker-dealer involved in a distribution of the same security-the "stabilization" problem-were made effective." During the late '50s and early '6os the Commission was concerned with the problems arising from the rapidly increasing number of offerings of securities which took place during the "new issuc" boom and the unethical selling practices engaged in by some broker-dealers during this period. There was a renewal of rule-making activity in 1962 when three rules dealing with different selling practices were promulgated ${ }^{59}$ and the "boiler room"

${ }^{50}$ The New York Stock Exchange and the NASD publish only the penalties and brief descriptions of the offenses in those disciplinary actions which involve serious violations. Special Study, pt. 4, 540, 667. The Special Study recommended that the disciplinary actions and underlying decisions of the New York Stock Exchange and the NASD be given greater publicity. If this recommendation is followed, these decisions will undoubtedly play a greater role in the development of standards as to selling practices.

${ }^{51}$ See H.R. Rep. No. $x_{3} 83$, 73d Cong., 2d Sess. 6-7 (r934).

62 The Exchange Act originally granted the Commission the power to enact any rules for the over. the-counter markets which it found to be in the public interest and necessary to accord investors protections comparable to those afforded in the exchange markets. 48 Stat. 895-96 (1934).

${ }^{83}$ The provision referred to in note 52 was repealed and Congress established the registration and revocation provisions for broker-dealers $\left(\$ I_{5}(b)\right)$, a general standard of conduct $(\$ 15(c)(1))$ with a specific grant of rule-making power, and certain other provisions. 49 Stat. 1375 (1936).

Rules IOb-I to $-3,15 \mathrm{CI}-\mathrm{I}$ to -8 .

35 Loss 1425 .

${ }^{80}$ Rules I5Cr-9 (1938), I5C2-I (1941), 10b-5 (1942), and 15C2-2 (1944).

${ }^{87}$ Rule I5c2-3.

${ }^{88}$ Rules rob-6, rob-7, and rob-8.

Rules rob-9, 15c2-4, and 15c2-5. 
rule, discussed below, was proposed. ${ }^{\text {e0 }}$ The Commission has since been occupied to a great extent with implementation of the Report of the Special Study ${ }^{61}$ and preparation of its legislative program which is currently before Congress. ${ }^{62}$

To recapitulate, there are now twenty-two rules under sections $10(b), 15(c)(I)$ and $15(c)(2)$. With the exception of rules 15 CI-I (which defines terms used in the other rules) and $15 \mathrm{cz}-\mathrm{I}$ (which deals with the hypothecation of over-the-counter securities), they are all concerned with various selling practices. They do not purport to cover the whole range of sales activities. They deal with several types of abuses, use different solutions and range greatly in specificity. The Commission has not sought to develop a group of rules to comprehend all, or even most, fraudulent practices; the gaps in the rules alone suggest the difficulty of such a task were it attempted.

Two of the rules prescribe a general standard of conduct which is no more specific than that found in the statute. Rules $x_{0} b_{-5}$ and $15 \mathrm{cr}-2$ are modeled on the general anti-fraud provision of section $I 7(a)$ of the Securities Act and make clear that the basic prohibitions against fraudulent practices apply to purchases and sales both by professional broker-dealers and by any other persons, and to over-the-counter as well as stock exchange transactions. ${ }^{63}$ In furtherance of this general aim, Rule rob-I makes the anti-manipulative provisions of section 9, which relate to securities registered for trading on exchanges, applicable to securities traded on exchanges but exempt from registration. ${ }^{64}$

Some rules are intended either to prohibit certain fraudulent representations or to establish requirements for the use of representations which would otherwise be misleading. Rule $15 \mathrm{Cr}-3$ makes it unlawful for a broker-dealer to represent that registration with the Commission indicates that the Commission has approved his business or any securities transaction which he effects. Recently promulgated rule rob-9 prohibits the representation that a distribution of securities is being made on an "all-or-none" basis unless one of the conditions of the offering is that all or part of the purchaser's consideration will be returned in the event that all of the securities being offered are not sold at a specified price within a limited period of time and the total amount due the seller is not received by him by a specified date. One rule deals specifically with representations in financial statements; rule $15 \mathrm{cr}-9$ requires that there be clearly set forth the assumptions upon which a pro-forma financial statement pur-

${ }^{\circ 0}$ Proposed Rule 15c2-6, SEC Securities Exchange Act Release No. 6885 (Aug. 16, 1962).

${ }^{61}$ SEC Securities Exchange Act Release No. 7290 (April 9, 1960); N.Y. Times, March 16, 1964, p. 47, cols. 6-8; SEC Securities Exchange Act Release No. 7218 (Jan. 9, 1964); SEC Rule 17a-8. Proposed Rule 15C2-7 which relates to over-the-counter quotations, if enacted, will be the first rule under the antifraud provisions resulting from the work of the Special Study. SEC Securities Exchange Act Release No. 7275 (March 24, 1964).

"s S. 1642, H.R. 6789, and H.R. 6793, 88th Cong., Ist Sess. (1963).

"Section Io(b), unlike $\$ \Upsilon_{5}(c)(1)$ and $15(c)(2)$, is not self-esecuting, and therefore Rule Iob-5 was necessary to impose the general prohibition in the statute on all purchases and sales.

"Rule rob-3 provides that it is unlawful for any broker or dealer, indirectly or direetly by the jurisdictional means, to engage in any practices prohibited under $\$ 15(c)$, as defined by the Commission. 
porting to give effect to the receipts from a public offering of securities is based.or

In various rules, the Commission has utilized the disclosure principle, which the statutes apply to securities offered publicly or listed on exchanges. Rule I5cI-4 sets out in detail the minimum information concerning every securities transaction to be included in the written confirmation which must be sent to the customer. The required information includes the capacity in which the broker-dealer is acting, whether as a broker or as principal for his own account, and, if as a broker, his commission or other remuneration and the name of the other party to the transaction or an offer to disclose it upon request. ${ }^{66}$ Other rules require disclosure of any control relationship between the broker-dealer and the issuer of the security involved in the transactions ${ }^{67}$ and of any financial interest of the broker-dealer in the distribution of the security. ${ }^{68}$

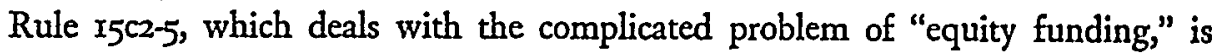
an interesting example of a rule that goes beyond the prohibition or disclosure devices used in other rules. Equity funding, which is also known as "secured funding" or "life funding," is the practice of purchasing securities, typically mutual fund shares, and then pledging the securities as collateral for loans the proceeds of which are used to pay the premiums on insurance policies purchased at about the same time. The purchaser often obtains the original funds for such transactions by liquidating or borrowing upon his previously acquired life insurance policy. The Commission learned that investment programs of this kind were being offered to persons whether or not such programs were appropriate for them and without adequate disclosures of the costs, risks and obligations involved. ${ }^{09}$ The rule compels written disclosures of certain important facts involved in such transactions; and it requires the broker-dealer to obtain information as to the financial situation of the investor so that a determination can be reached whether the transaction as a whole is suitable for him and a written statement can be furnished to him setting forth the basis for this determination. This rule, like certain other rules developed under the anti-fraud provisions, is an example of the use of the rule-making power to articulate a detailed regulatory scheme for a new problem which probably could not have been developed as quickly by the ad hoc approach of administrative or judicial proceedings, which depends upon the building of a record in a particular case. It should be noted, however, that a court recently found that an insurance agent had committed common law fraud by persuading the plaintiff to enter into a complicated bank-financed insurance plan which was clearly not suitable for him. ${ }^{70}$

\footnotetext{
${ }^{o x}$ See also Rules $1_{5 c x}-3$ and $15 c x-8$.

${ }^{\circ}$ The Special Study recommended that current disclosure requirements, including those made on confirmations, be improved to provide additional information in particular types of transactions. Special Study, pt. 2, at 677-78.

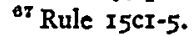

${ }^{68}$ Rule I5cr-6.

${ }^{68}$ SEC Securities Exchange Act Release No. 6809, at I. (May 22, 1962).

${ }^{70}$ Anderson v. Knox, 297 F.2d 702 (9th Cir. 196r), affirming Knox v. Andersion, I 59 F, Supp. 795 (D. Hawaii, I958), I62 F. Supp. 338 (D. Hawaii, 1958).
} 
Although formal rules make possible detailed regulation, difficult problems are frequently encountered in attempting to deal in this way with the complex financial practices involved in the distribution and trading of securities. A good illustration is presented by the Commission's stabilization rules. These rules were promulgated partly as a result of congressional dissatisfaction with the operation of the informal procedures which had been used. ${ }^{71}$ Prior to adoption, they were given thorough consideration over a substantial period of time by members of the securities industry and the Commission. Nevertheless, the Commission found it necessary to allow for Alexibility in their administration by including general exemption clauses within the rules to deal with practices which would not have an adverse effect on investors but technically were within the prohibitions of the rules. It was also necessary to state, when the rules were made effective, that because particular practices were not prohibited under the provisions of the rules did not mean they could not be found unlawful under the statute or other rules. ${ }^{72}$ The rules were based on considerable prior administrative experience and their meaning has been explained in innumerable informal conferences since they became effective. Nevertheless, the Special Study recently indicated that one of them, rule rob-6, which the Commission has interpreted in several cases, ${ }^{73}$ was subject to misunderstanding and in need of further clarification. ${ }^{74}$

Several rules dealing with various selling practices are not subject to generalization. These include rules concerning the payment of special compensation to induce a third person to buy a security by a dealer interested in a distribution of the security, ${ }^{75}$ prohibiting "churning" of discretionary accounts, ${ }^{76}$ and rules which make it unlawful to engage in over-the-counter transactions in securities when the Commission has suspended trading in that security on the exchanges ${ }^{77}$ or to trade in pre-war German securities unless such securities have been validated by the authority established for that purpose. ${ }^{78}$

Despite these differences among the various rules, they do have certain similarities. Most of them declare specific acts or practices fraudulent within the meaning and prohibitions of the statutes. ${ }^{79}$ Since they substantially implement a statutory policy and are issued pursuant to a statutory grant of specific rule-making power, courts, theoretically at least, should give them the deference accorded legislative pronounce-

72 Lass $158 . x-82$.

${ }^{73}$ SEC Securities Exchange Act Release No. 5194, at 3 (July 5, r955).

${ }^{78}$ Theodore A. Landau, SEC Securities Exchange Act Release No. 6792, at 5-6 (April 30, 1962); Bruns, Nordeman \& Co., 40 S.E.C. 652, 659-6r (1961). See also SEC v. Scott, Taylor, Inc., 183 F. Supp. 904 (1959).

"Special Study, pt. I, at 559. For a detailed discussion of problems under this rule see Whitney, Rule rob-6: The Special Study's Rediscovered Rule, 62 Micr. L. Rev. 567 (1964).

${ }^{78}$ Rule rob-2.

${ }^{70}$ Rule $15 \mathrm{Cr}-7$.

TRule I5c2-2.

${ }^{78}$ Rule 15C2-3.

${ }^{50}$ Exceptions to this definitional approach aro Rules rob-2, rob-3 and rob-5. 
ments. ${ }^{80}$ Few of the rules constitute outright prohibitions of specific practices; rather they permit certain acts so long as the safeguards in the rule are met. Thus, the Commission has recognized that many practices in the securities industry which have been and can be used for improper purposes may also be carried on in accordance with high ethical standards. ${ }^{81}$

\section{Commission Use of Adjudication}

Since the Exchange Act was enacted thirty years ago, many administrative proceedings have been concerned with broker-dealer selling practices. Although proceedings often are based on injunctions granted by the courts or involve stipulations in which the respondent broker-dealers agree to findings of violations and to revocation or some other sanction, many of them have been strongly contested. These proceedings, particularly the contested ones, have provided opportunities for the development of standards and rules under the statutory prohibitions. The Commission's approach to them is based on the view, endorsed by the courts, that the obligations imposed by the anti-fraud provisions of the securities acts are not limited to those recognized in conventional common law fraud doctrines. ${ }^{82}$ Under this approach, the anti-fraud provisions not only prohibit gross frauds such as misappropriation of funds and outright falsehoods, but also those acts that violate the obligation of fair dealing which the Congress believed was required of professional broker-dealers and their salesmen because of the very nature of the securities business. As a result, the decisions in the administrative proceedings have articulated general theories and rules as to specific practices which establish a high standard of conduct for broker-dealers in their relations with customers. As discussed below, the courts generally have sustained these interpretations of the meaning and intent of the anti-fraud provisions.

Commission decisions as to the obligations of broker-dealers to their customers are usually rationalized as falling within two theories. These are known as the "shingle" or "implied representation" theory and the "fiduciary" or "trust and confidence" theory. ${ }^{83}$ Both emphasize the intricate nature of the merchandise involved and the need for protection of the average investor from sharp practices by the usually more sophisticated broker-dealer. The first theory, which is the broader of the two, holds that merely by hanging up his shingle, i.e., doing business

\footnotetext{
${ }^{80}$ I Davis 299. A large amount of legal scholarship has been expended on the distinction between "interpretative" and "legislative" rules. $1 d$. $\$ 55.03$ and 5.04. Without attempting to analyze the decisions of the courts with respect to this distinction, it is believed, as suggested in the text, that the Commission's anti-fraud rules fall within the "legislative" category.

${ }^{81}$ See H.R. REp. No. 1383, 73d Cong., 2d Sess. 6-7 (1934).

${ }^{82}$ B. Fennekohl \& Co., SEC Securities Exchange Act Release No. 6898, at 6 (Sept. 18, 1962); Cady, Roberts \& Co., 40 S.E.C. 907, 910 (I96x). See Norris \& Hirshberg v. SEC, 177 F.2d 228, 233 (D.C. Cir. 1949); Charles Hughes \& Co. v. SEC, 139 F.2d 434, 437 (2d Cir. 1943), cert. denied, 321 U.S. 786 (1944).

${ }^{83}$ See 3 Loss 1482-1508. Also see Comment, 62 Micr. L. Rev. 730, 734-35 (1964); Loomis, The Securities Exchange Act of $x 934$ and the Investment Advisers Act of 1940, 28 GEO. WASH. L. REv. 214, 240 (1959).
} 
with the public, the broker-dealer impliedly represents that he will deal fairly with his customers in accordance with the standards of the profession. ${ }^{84}$ It might be argued that, since the shingle theory is couched in terms of an implied representation, disclosure by the broker-dealer of the nature of the questioned conduct and its inconsistency with accepted standards, would prevent the conduct from constituting a violation of the anti-fraud provisions. However, the non-disclosure of the unethical conduct does not appear to be the controlling factor in this area. A brokerdealer is not likely to disclose to his customer that he is engaging in conduct which falls short of meeting general standards of fairness, and, therefore, such a disclosure is rarely asserted as a defense to charges of misconduct-although alleged sophistication or awareness by the customer is. However, apart from the question of what factual proof would be deemed sufficient to establish that adequate and meaningful disclosure was made in a situation where the customer was dealt with on the basis of lesser standards of fairness, the Commission has indicated in some cases that the proscribed fraudulent conduct would not be cured by such disclosure. ${ }^{85}$

The second theory was articulated in cases involving situations in which the broker-dealer had placed himself in a special position of trust and confidence with the customer. ${ }^{86}$ This theory is that in such a situation a broker-dealer owes the customer the fiduciary's duties to disclose the nature and extent of any interest he may have in the transactions and to act in the customer's best interests. ${ }^{87}$ And he is not relieved of this duty because he has executed the transaction as a dealer for his own account rather than as broker for the customer. ${ }^{88}$

Although referred to as separate doctrines, these theories are, in fact, closely connected. They developed at approximately the same time in cases in which the Commission pointed out that the duty of securities dealers to treat their customers fairly resulted from holding themselves out as possessing specialized knowledge and skill and from cultivation of their customers' trust and confidence. ${ }^{89}$ These theories can be viewed as different ways of characterizing the obligation imposed

\footnotetext{
84 E.g., Mac Robbins \& Co., SEC Securities Exchange Act Release No. 6846, at 3 (July Ir, r962); Carl J. Bliedung, 38 S.E.C. 518, 52 r (I958); E. H. Rollins \& Sons, Inc., I8 S.E.C. 347,362 (1945).

${ }^{85}$ Mac Robbins \& Co., supra note 84, at 4 n.I5; Powell \& McGowan, Inc., SEC Securities Exchange Act Release No. 7302, at 2 (April 24, 1964).

${ }^{80}$ E.g., Haley \& Co., 37 S.E.C. 100, 106 (1956); Arleen W. Hughes, 27 S.E.C. 629, 638 (1948); Norris \& Hirshberg, Inc., 21 S.E.C. $865,882-83$ (I946).

${ }^{87}$ Looper \& Co., $3^{8}$ S.E.C. 294, 300 (I958); Arleen W. Hughes, supra note 86, at 636 (1948).

${ }^{\text {Bo }}$ Herbert R. May, 27 S.E.C. 813, 829-30 (1948); Allender Co., 9 S.E.C. ro43, 1053-54 (1941).

It is interesting to note that English brokers seem to consider that the "trust and confidence" theory applies to all of their relationships with their customers. The London Stock Exchange forbids advertising by member firms. In consequence, the back cover of each issue of The Stock Exchange Journal of the London Stock Exchange contains the following legend: "As the relationship between Stockbroker and Client is one of mutual trust and confidence, the Council of the Stock Exchange consider that the best way for a member of the public to get into touch with a Broker is by personal introduction." [Emphasis supplied.] The exchange offers to provide interested persons with lists of member firms.

sv Allender Co., supra note 88, at 1053-57; Jansen \& Co., 6 S.E.C. 391, 394 (1939); Duker \& Duker, 6 S.E.C. $386,388-89$ (1939). See Loss, The SEC and the Broker-Dealer, I VANd. L. REv. 516,527 (1948). Also sec 1o S.E.C. ANN. REP. 74 (I944).
} 
upon all broker-dealers by the statutory provisions in varying contexts. Recent Commission decisions have tended to rely upon, and to articulate more fully, the obligations which the shingle theory imposes on broker-dealers, and to emphasize the obligations which broker-dealers owe to all customers regardless of the existence of any special reliance or dependence. ${ }^{90}$

Under the general theories which rationalize this approach, Commission decisions have developed rules on specific practices which, like the rules promulgated under the formal rule-making power, vary greatly in their scope. The case rule with the widest application, and the first one which the Commission derived from the shingle theory, relates to the prices charged or paid public customers by brokerdealers. In an early case, the Commission held that a broker-dealer impliedly represents that the prices he charges his customer will bear a reasonable relationship to the current market price of the security. ${ }^{91}$ If the prices charged are not so related to the market price and the broker-dealer does not adequately disclose that fact, he has failed to meet the terms of his implied representation and has violated the anti-fraud provisions. ${ }^{92}$ The reasonableness of the relationship to the current market is tested by the mark-up over the prevailing wholesale market price for the security without regard to the actual cost of the security to the broker-dealer except insofar as that is indicative of the current market price. ${ }^{93}$ The rule does not limit the broker-dealer's profit on securities which he purchased earlier at prices below the current market price and has kept in his inventory. In a number of cases the Commission has elaborated on the rule, ${ }^{94}$ but no attempt has been made to define what is a reasonable spread in relation to the current market in all cases. The NASD, under its own rule that prices be "fair, taking into consideration all relevant circumstances," ${ }^{25}$ has suggested that, in most cases, a mark-up of five per cent or less will not be considered unreasonable. ${ }^{96}$

Other selling practice rules of wide applicability developed through adjudication concern representations, disclosures, manipulation and the duty of supervision. The anti-fraud provisions expressly prohibit false and misleading statements of a material nature. The Commission has held that these provisions prohibit statements made without adequate basis, ${ }^{97}$ even though the person making them may believe

\footnotetext{
${ }^{\circ 0}$ E.g., Aircraft Dynamics International Corp., SEC Securities Exchange Act Release No. 7r13, at 5 (Aug. 8, I963); Heft, Kahn \& Infante, Inc., SEC Securities Exchange Act Release No. 7020, at 4 (Feb. II, I963); Mac Robbins, supra note 84; W. T. Anderson Co., 39 S.E.C. 630, 636 (1960); Batkin \& Co., 38 S.E.C. 436, 446 (r958). The Commission's decision in J. Logan \& Co., SEC Securitics Exchange Act Release No. 6848, at Io (July 9, 1962), decided just before the Mac Robbins case, is a recent example of a decision which is primarily based on the shingle theory, but which also cmphasizes the customer's trust and confidence in the broker. See also Powell \& McGowan, Inc., supra note 85.

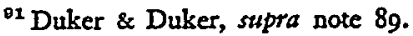

2 lbid.

${ }^{98}$ G. Alex Hope, 7 S.E.C. 1082, 1084 (1940).

- See 3 Loss $I_{4} 88$.

${ }^{\circ 5}$ Rules of Fair Practice, art. III, $\$ 4$, NASD Manual D-6.

"NASD Manual. G-3.

${ }^{\circ 7}$ E.g., Barnett \& Co., 40 S.E.C. 521 (Ig6r); Leonard Burton Corp., 39 S.E.C. 211 (r959).
} 
them. ${ }^{98}$ Thus broker-dealers have a duty of investigation. ${ }^{89}$ This rule applies to statements in the form of opinions as well as statements of fact, ${ }^{100}$ and, in the case of predictions, it is immaterial that they ultimately prove correct if the person making them had no basis on which to make them at the time. ${ }^{101}$ The Commission has also stated that the concept of "puffing" can have little application in the securities industry. ${ }^{102}$ The Commission has spelled out what disclosures the brokerdealer must make when he has established a relationship of trust; these include disclosure of the cost of the security and its current market price where that is better than the price charged, as well as the capacity in which he is acting. ${ }^{103}$ In addition, as a fiduciary, he has a duty to disclose any interest he may have in the transaction adverse to that of his customer. ${ }^{104}$ In the area of manipulation, the Commission has, in its opinions, made clear that the standards are uniformly applicable to all brokerdealers. In section 9 of the Exchange Act, Congress expressly prohibited exchange transactions creating trading in a security or affecting its price for the purpose of inducing transactions by others and certain other manipulative practices, such as wash sales and matched orders. The Commission has made clear that these antimanipulative provisions also apply to over-the-counter transactions. ${ }^{105}$ The securities acts contain no provision specifically requiring a broker-dealer to supervise the conduct of his salesmen. After a period of development, the Commission has established the case rule that a broker-dealer violates the anti-fraud provisions when his employees engage in misconduct which violates the provisions and the brokerdealer did not properly perform his duty to prevent such misconduct. ${ }^{106}$

Other case rules, like certain formal rules, deal only with a particular unethical practice not involved in a broad range of broker-dealer activity. Examples of these are decisions that hold it to be a fraudulent practice to effect unauthorized transactions, ${ }^{107}$ without proper disclosure to fail to consummate transactions and to deliver securities promptly, ${ }^{108}$ and to sell securities subject to a lien ${ }^{109}$ or to accept customers' funds while insolvent. ${ }^{110}$ An interesting example of a case rule closely related to a formal rule is that which applies the ban against excessive trading in discretionary

${ }^{08}$ Alexander Reid \& Co., SEC Securities Exchange Act Release No. 6727, at 5 (Feb. 8, 1962).

${ }^{\circ 0}$ See SEC Securities Exchange Act Release No. 672I, at 3 (Feb. 2, 1962) (statement of policy). Cf. Standard Bond \& Share Co., 34 S.E.C. 208 (r952).

${ }^{100}$ Ross Securities, Inc., SEC Securities Exchange Act Release No. 7069, at 5 (April 30, r963).

${ }^{202} \mathrm{Heft}$, Kahn \& Infante, Inc., supra note go.

${ }^{102}$ B. Fennekohl \& Co., supra note 82, at 5-6 (Sept. 18, I962).

${ }^{108}$ Arleen W. Hughes, supra note 86 , at 637 .

${ }^{206}$ Ramey Kelly Corp., 39 S.E.C. 756, 76I (I960); Mason, Moran \& Co., 35 S.E.C. 84, 90 (1953).

${ }^{100}$ Barrett \& Co., 9 S.E.C. 3 Ig, 328 (I94I). See 3 Loss $1563-68$.

${ }^{100}$ Sutro Bros. \& Co., SEC Securities Exchange Act Release No. 7052, at I5-19 (April 10, 1963);

Reynolds \& Co., 39 S.E.C. 902, 9I6-I7 (I960). The amendments to the securities acts currently being considered by Congress make failure to supervise a statutory basis for revocation.

${ }^{107}$ First Anchorage Corp., 34 S.E.C. 299, 304 (1952).

${ }^{108}$ E.g., Carl J. Bliedung, 38 S.E.C. 5I8, 52 (I958); Lewis H. Ankeny, 29 S.E.C. 5I 4, 516 (I949).

See also SEC Securities Exchange Act Release No. 6778 (April 16, 1962) (statement of policy).

${ }^{109}$ Richard A. Sebastian, 38 S.E.C. 865,868 (1959).

${ }^{110}$ E.g., Batkin \& Co., 38 S.E.C. 436,446 (1958); W. F. Colly \& Co., 3 I S.E.C. 722, 726 (1950). 
authority accounts found in rule $15 \mathrm{cr}-7$ to accounts controlled by the broker-dealer because of the customer's reliance on his recommendations. ${ }^{111}$

One group of recent case rules deals with a problem, that of boiler-room operations, with which the Commission has attempted to deal by a formal rule. While all of the characteristics are not found in each case and boiler rooms take various forms, the term is generally used to describe a broker-dealer firm which typically sells low-priced, speculative and obscure securities over the long-distance telephone to customers who are unknown to the salesman, through intensive, "high-pressure" selling methods, including misrepresentation. ${ }^{112}$ The unethical methods used provide a basis for proceeding against these broker-dealers under the general anti-fraud provisions of the statutes and that is the course which the Commission has followed. However, much damage often has been done to public investors before the evidence of such violations is accumulated and presented to the courts or to the Commission in administrative proceedings. ${ }^{113}$ Moreover, there are substantial problems in obtaining the witnesses, scattered throughout the country, and in proving fraudulent representations made over the telephone. Boiler-room operations seemed to become more prevalent in the recent bull market and the prosecution of such cases placed a heavy burden on the Commission's enforcement staff. In $\mathrm{r} 962$ the Commission proposed rule $15 \mathrm{c2}-6$, which, subject to certain exemptions, would make it unlawful for a broker-dealer to offer or sell by telephone equity securities at a price of $\$$ ro or less to persons other than regular customers. ${ }^{114}$ The proposed rule would establish record-keeping requirements for such transactions to facilitate a determination whether the securities or transactions are exempt from its prohibitions. It has been objected to strongly by the securities industry primarily on the grounds that it is too sweeping in coverage, since most securities firms sell low-priced stock over the telephone, and that the extensive record-keeping requirements place too heavy a burden on ethical broker-dealers as a price for detecting those who are not. ${ }^{110}$ The Commission has as yet taken no final action with respect to the proposed rule.

Since the rule was proposed, however, the Commission issued a number of decisions which have dealt very specifically with boiler-room operations. The second Mac Robbins decision, discussed further below, emphasized that a salesman in a boiler room could not rely, without further investigation, on the information

${ }^{111}$ Looper \& Co., 38 S.E.C. 294, 300-or (I958); R. H. Johnson \& Co., 36 S.E.C. 467,485 (1955), aff'd sub nom., R. H. Johnson \& Co. v. SEC, 23 I F.2d 523 (D.C. Cir. 1956), cert. denied, 352 U.S. 844 (1956). . . .

${ }^{122}$ See Special Study, pt. I, at 265-68. The boiler room is not a new or uniquely American phenomenon. The term was used in a judicial decision as early as I937. United States v. Rollnick, 91 F.2d 911, 915 (2d Cir. I937). Similar broker-dealer activities in England led to a Board of Trade report on "Share-Pushing," CMD. No. 5539 (1937), which resulted in the Prevention of Fraud (Investments) Act, 1939, 2 \& 3 Geo. 6, c. 16, revised by Prevention of Fraud (Investments) Act, 1958, 6 \& 7 Eliz. 2, c. 45. ${ }_{113}$ It has been asserted that one large boiler-room operator sold over $\$ 20$ million in securities before being convicted of fraud and sentenced to a prison term. Special Study, pt. 1, at 266.

114 SEC Securities Exchange Act Release No. $688_{5}$ (Aug. I6, I962).

${ }^{116}$ For a discussion of the issues involved, see Comment, 72 YALE L.J. I4II (1963). 
furnished by his employer as a basis for representations to his customers. ${ }^{116}$ In other cases, the Commission held that a research analyst who prepared a fraudulent "market letter" on the instructions of his employer was a "cause" of the revocation of his employer's broker-dealer registration ${ }^{117}$ and that a salesman in a boiler-room operation who knowingly turned a customer over to a "dynamiter," the ultimate persuader of the customer, bore the responsibility for the fraudulent and misleading statements made by him. ${ }^{118}$ In these and other cases, ${ }^{119}$ the Commission has stressed the idea that boiler-room operations are designed to induce a hasty decision by the customer and that no effort is made by the salesman, or opportunity provided to his customer, to determine whether the security recommended is suitable for the customer to whom it is recommended. These cases seem to suggest the rule, not yet expressly stated, that a practice of recommending speculative securities indiscriminately on the telephone to unknown persons in an intensive sales campaign-the usual characteristics of a boiler room-constitutes a course of conduct which is prohibited under the anti-fraud provisions and is a basis for revocation. ${ }^{120}$ Such a principle would achieve many of the aims of proposed Rule ${ }_{55} \mathrm{c} 2-6$, without creating some of the problems raised by the proposed rule.

In any consideration of the standards which the Commission has developed by adjudication, the Commission's influence on the self-regulatory organizations must be considered. The Commission has certain powers to abrogate and supplement the rules of the self-regulatory organizations. ${ }^{121}$ Despite the existence of these powers, the Commission generally has followed the practice of consulting informally on rule changes or proposed new rules, rather than taking formal administrative action. ${ }^{122}$ The Commission's views as to fair dealing and standards of sales practices have been reflected, at least in part, in the rules, interpretations and statements of policy of the self-regulatory institutions. ${ }^{122 a}$ The statute vests in the Commission specific review authority only with respect to NASD disciplinary proceedings. ${ }^{123}$ Nevertheless, the Commission has used this power much the way courts perform such a function in reviewing administrative agency actions, and it has proved to be a fruitful source for Commission opinions discussing sales practices within the concepts of "high standards of commercial honor" and "just and equitable principles of trade."124

\footnotetext{
${ }^{116}$ Mac Robbins \& Co., supra note 84 , at 12.

${ }^{117} \mathrm{Heft}$, Kahn \& Infante, Inc., supra note 90.

${ }^{118}$ Ross Securities, Inc., supra note Ioo.

${ }^{110}$ J. Logan \& Co., supra note go; Best Securities, Inc., 39 S.E.C. 93 I (I960).

120 The Special Study recommended further implementation of the concept of suitability as a standard for all broker-dealer firms. Special Study, pt. $\mathrm{I}$, at 329.

121 Exchange Act $\S \S 15 A(k)(I)$ and (2), and $19(b)$.

${ }^{120}$ Spccial Study, pt. 4, at 7 I I-17.

${ }^{122 a}$ Sec, e.g., Rules of Fair Practice and Interpretations, Policies, and Explanations, NASD ManuaL; Rules $40 \mathrm{I}-\mathrm{rI}$ and supplementary material thereto, 2 NEw YoRx STOCK EXCFANGE GuIDE II 240I-II.70; Rules 410-22, American Stock Exchange Guide QT 9430-42.

${ }^{123}$ Exchange Act $\$ 15 A(g)$. See also Silver v. New York Stock Exchange, 373 U.S. 341 (1963).

124 Rules of Fair Practice, art. III, § I, NASD ManUaI D-5.
} 
The NASD generally has attempted to apply a "businessman's approach" in its disciplinary proceedings and the decisions of its Board of Governors usually have not contained extended discussions of the principles applied. ${ }^{125}$ On review, the Commission has often elaborated on the finer points involved in the case and discussed the general meaning of the particular selling practice rule involved. Commission decisions have been particularly important in the development of the NASD standards on fair prices under the "five per cent policy" mentioned above, ${ }^{120}$ the NASD rule concerning suitability of recommendations, ${ }^{127}$ the policy against "freeriding" or withholding of securities by a broker-dealer involved in a distribution of those securities, ${ }^{128}$ the duty of broker-dealers to investigate the backgrounds of their salesmen before hiring them, ${ }^{129}$ and the duty of a broker-dealer to supervise his salesmen. ${ }^{130}$ The Commission's decisions on review of NASD actions have an important effect not only because they publicize and rationalize NASD interpretations of its own selling practice standards but because most broker-dealers, including exchange members, are members of the NASD ${ }^{131}$ and thus subject to enforcement action by that organization. ${ }^{132}$

\section{Commission's Use of Statements of Policy}

Throughout its history, the Commission has issued statements of policy to announce its position on various problems. Published as releases under the particular acts to which they relate, they are in the form of discussions by the Commission or expressions of opinion by a high staff official. In recent years, the Commission has also followed the policy of elaborating more fully on the purpose or application of a new rule in the releases proposing it or declaring it effective. In relative terms the number of published policy statements is small when compared with the informal administrative interpretations which are furnished to interested persons or their counsel by letter or over the telephone. ${ }^{133}$ These interpretations are made by staff members, but often, when they involve an important policy matter or a close

${ }^{125}$ Special Study, pt. 4, 664-65.

${ }^{220}$ General Investing Corp., SEC Securities Exchange Act Release No. 7316 (May 15, 1964); Naftalin \& Co., SEC Securities Exchange Act Release No. 7220 (Jan. 1o, r964); Boren \& Co., 40 S.E.C. 2xy (I960).

${ }^{127}$ First Securities Corp., 40 S.E.C. 589 (196r); Gerald M. Greenberg, 40 S.E.C. 133, 137-38 (1960).

${ }^{228}$ L. H. Rothchild \& Co., SEC Securities Exchange Act Release No. 7182 (Dec. 3, 1963); First California Company, 40 S.E.C. 768 (Ig6r).

${ }^{238}$ Vickers, Christy \& Co., SEC Security Exchange Act Release No. 6872 (Aug. 8, 1962).

${ }^{230}$ First Securities Corp., 40 S.E.C. 589 (196r).

181 Special Study, pt. I, 16.

${ }^{182}$ As proposed by the Commission and enacted by the Senate, the amendments to the securitics acts currently before the Congress would require all broker-dealers registered with the Commission to be members of the NASD. S. I642, 88th Cong., rst Sess. (I963). The amendments recommended to the House of Representatives by its Committee on Interstate and Foreign Commerce, however, do not require NASD membership for all registered broker-dealers, but give the Commission the power to exercise functions similar to the NASD with respect to nonmember brokcr-dealers. H.R. 6793, 88th Cong., 2d Sess. (1964). Whichever formula is finally adopted, the importance of the Commission's appellate function over NASD disciplinary proceedings is likely to increase.

${ }^{188}$ See 3 Loss $1894-97$. 
decision, they are first cleared with the Commission. These informal interpretations deal with matters arising under all the statutes administered by the Commission and usually take the form of statements that the staff will recommend that the Commission take "no action," assuming that the facts are true as stated, or, when appropriate, that compliance with the pertinent statute or rule is required. Because of problems involved in determining all the relevant facts, the intent of the parties, and the ultimate purpose of the transaction, as a matter of policy, the Commission and its staff are reluctant to express a view whether proposed transactions violate the anti-fraud provisions. ${ }^{134}$

In the selling practice area, the publication of general policy statements has assisted the Commission in the development of standards. Early examples are releases pointing out how trading activities of broker-dealers involved in a distribution of securities, which raise the price of that security, may violate the anti-manipulative provisions of both the Securities Act and the Exchange Act, ${ }^{135}$ and how broad "hedge clauses" in broker-dealer sales literature may violate the anti-fraud provisions. ${ }^{136}$ More recently, a release pointing out the abuses in "hot issue" distributions ${ }^{137}$ preceded an NASD interpretation prohibiting the practice of "free-riding"138 and special NASD enforcement action thereunder.

The statement setting out the most specific guide-lines on selling practices relates to literature used in the offer and sale of investment company securities. ${ }^{139}$ The statement was published as a release under the Securities Act and Investment Company Act of I940, but actions contravening its provisions may also constitute a violation of the anti-fraud provisions of the Exchange Act. It sets out in detail the types of representations and omissions which will be considered materially misleading in investment company sales literature, prescribes the kinds of performance charts and tables which can be used in such literature, and gives examples of the permissible charts and tables. The NASD has established a procedure for reviewing sales literature before its use by members to make sure that it complies with the statement. ${ }^{140}$

Some statements have been used primarily as warning devices, pointing out how established policies apply to a particular problem, although they may also serve to develop these policies further. Examples are the statement which sets out in detail the responsibilities of broker-dealers when distributing securities which have not

104 A notable exception to this policy relates to the giving of interpretations whether proposed activities in connection with securities distributions will violate the stabilizaton rules.

${ }^{105}$ SEC Securities Exchange Act Release No. 3505 (Nov. 16, I943).

${ }^{100}$ SEC Securities Exchange Act Release No. 4593 (April 10, 1951).

${ }^{137}$ SEC Sccurities Exchange Act Release No. 6097 (Oct. 23, 1959).

180 NASD MaNUAI, G-23-26.

${ }^{180}$ SEC Securitics Act Release No. 3856 (Oct. 3I, r957) and accompanying Statement of Policy. The statement was first issued in 1950, SEC Securities Act Release No. 3385 (Aug. 14, 1950) and has been revised twice since then, in 1956, SEC Securities Act Release No. 3669 (Aug. 9, 1956) and in 1957, SEC Securities Act Release No. 3856, supra.

${ }^{140}$ See Boren \& Co., 40 S.E.C. 217,223 (1960). 
been registered under the Securities Act, ${ }^{141}$ and the one pointing out the dangers in too glowing statements about a certain foreign stock when it first became available in the United States and financial data concerning the issuer was not available. ${ }^{142}$

The self-regulatory organizations make substantial use of the statement of policy device. The NASD and the exchanges have published many formal interpretations of their rules which are incorporated into the official collections of their constitutions, by-laws and rules. ${ }^{143}$ Concerning selling practices, the New York Stock Exchange has just published a complete revision of its rules and interpretations concerning advertising, research reports, and sales literature used by broker-dealers ${ }^{144}$ and a new interpretation of its supervision rule, ${ }^{144 a}$ and the NASD is currently revising its rules and interpretations in both of these areas.

\section{E. Court Reaction to Commission Selling Practice Rules and Standards}

As suggested earlier, Commission materials have provided the main source of published statements as to the standards applicable to broker-dealer selling practices since the passage of the securities acts. There have not been many court decisions expounding upon the express civil liability provisions of the acts. ${ }^{145}$ A large body of law has developed as a result of court decisions which have implied a civil liability for violation of section Io(b) of the Exchange Act and rule Iob-5 thereunder, ${ }^{140}$ but these cases generally have not involved broker-dealer selling practices. For these reasons the significant court decisions in this area generally have been in cases involving some sort of Commission action, that is, criminal cases in which the Commission assists the Department of Justice, ${ }^{147}$ Commission requests for injunctions, ${ }^{148}$ and appeals from Commission administrative action. ${ }^{140}$ The court decisions

${ }^{141}$ SEC Securities Act Release No. 4445 and SEC Securities Exchange Act Release No. 672I (Feb. 2, 1962).

${ }_{142}$ SEC Securities Exchange Act Release No. 6525 (April 12, 1961). Another example of such a statement of policy is that which warned that it was a violation of the implied representation of fair dealing for a broker-dealer to delay delivery of securities purchased by a customer unless he previously disclosed his intent to do this. See SEC Securities Exchange Act Release No. 6778 (April 16, 1962).

${ }^{142}$ NASD Manuar; New York Stock Exchange Guide; American Stock Exchange Guide.

242 NEW YoRK STOCK EXCHANGe GuIDE II 247 I-74A.

${ }^{14 \$ a}$ New York Stock Exchange, Member Firm Educational Circular No. 189, May 1, 1964.

${ }^{165}$ Securities Act $\$ \S \mathrm{II}$ and 12 ; Exchange Act $\$ \S 9(\mathrm{e})$ and $I 8(\mathrm{a})$. Sce 3 Loss, I682-92, I746-47. The statement in the text does not apply to the special civil liability for short-term trading by corporate "insiders" imposed in $\S 16(\mathrm{~b})$, which has given rise to much litigation. Sce 2 Loss 1040-90. A recent example of a case under the express civil liability provisions that did involve selling practices is Herring v. Hendison, 218 F. Supp. 419 (S.D.N.Y. 'r 663 ).

${ }^{140}$ See 3 Loss I757-97.

${ }_{147}^{14 . g .,}$ United States v. Dardi, $4 \mathrm{CCH}$ Fed. Sec. L. Rep. I9I,342 (2d Cir., Mar. 17, 1964); United States v. Benjamin, 4 CCH Fed. Sec. L. Rep. I91,329 (2d Cir., Feb. 17, 1964); and United States v. Ross, 32x F.2d 6r (2d Cir. r963).

${ }^{148}$ E.g., SEC v. Capital Gains Research Bureau, Inc., 375 U.S. 180 (1963); SEC v. F. S. Johns \& Co., 207 F. Supp. 566 (D. N.J. 1962 ).

${ }_{240}$ E.g., Berko v. SEC, 316 F.2d 137 (2d Cir. I963); R. H. Johnson \& Co. v. SEC, 231 F.2d 523 (D.C. Cir. I956), cert. detried, 352 U.S. 844 (1956).

Court decisions up to Dec. $3 \mathrm{I}$, 1948 involving all of the statutes administered by. the Commission are collected in Securities and Exchange Commission Judicial Decisions, Vols. $x-5$, published by the Government Printing Office. The Commission's staff is currently bringing this collection up to date, and 
have generally supported the selling practice standards enunciated by the Commission, ${ }^{150}$ and some have added significantly to them. ${ }^{151}$

More decisions on selling practices seem to have arisen in cases involving court review of action by the Commission denying or revoking a broker-dealer registration. Courts of appeals have upheld Commission decisions articulated under the shingle theory and the fiduciary theory. In the early case of Charles Hughes $\&$. Co. v. $S E C^{152}$ the Court of Appeals for the Second Circuit reviewed a revocation case based upon a finding that the broker-dealer had charged prices unrelated to the current market without disclosing that fact. The court noted that it did not have to determine whether common law fraud had been established. It stated that "the essential objective of securities legislation is to protect those who do not.know market conditions from those who do."153 The court agreed with the Commission that the charging of excessive prices without disclosing that fact constituted a violation of the anti-fraud provisions. One of the first Commission decisions in which it clearly applied the fiduciary theory, Arleen W. Hughes, ${ }^{154}$ was subsequently upheld on review by the United States Court of Appeals for the District of Columbia. ${ }^{155}$ In that case, the court stated that the securities industry "by its nature, requires specialized and unique legal treatment." Other decisions by the courts of appeals have recognized that the public needs special protection in the securities industry because of the ever-present opportunities for dishonesty and the fact that fraudulent activities may assume subtle and involved forms. ${ }^{150}$

Despite the number of opinions by lower federal courts, the Supreme Court had not considered the general meaning of the anti-fraud provisions in any decision until I963 when it decided SEC v. Capital Gains Research Bureau, Inc. ${ }^{157}$ That was a proceeding for a preliminary injunction based on the anti-fraud provision of the Investment Advisers Act of I940 which, like the anti-fraud rules under the Exchange Act, was modeled on section I7(a) of the Securities Act. ${ }^{158}$ The defendant

it is hoped that volume 6, covering the period from Jan. I, 1949 through Dec. 3I, I950, will be published scon.

${ }^{100}$ But see United States v. Crosby, 294 F.2d 928 (2d Cir. 196r), and the discussion of this decision is the release cited supra note $\mathrm{I}_{4} \mathrm{I}$.

${ }^{161}$ E.g., SEC v. Capital Gains Research Bureau, Inc., supra note \} _ { 4 } 8 \text { ; United States v. Benjamin, } supra note I47; Charles Hughes \& Co. v. SEC, I39 F.2d 434 (2d Cir. 1943), cert. denied, 32 I U.S. 786 (1944).

102 Supra note 151 .

103 × 39 F.2d at 437 .

10627 S.E.C. 629 ( 1948 ).

${ }^{165}$ Hughes v. SEC, ${ }_{74}$ F.2d 969 (D.C. Cir. 1949):

${ }^{150}$ Norris \& Hirshberg v. SEC, I77 F.2d 228, 233 (D.C. Cir. I949); Archer v. SEC, I33 F.2d 795, 803 (8th Cir. 1943). Although the courts approved these applications of the shingle and fiduciary theories, they did not discuss the theories as such. In his concurrence in Kahn v. SEC, 297 F.2d II2, 114 (2d Cir. I96I), Judge Clark, who wrote the opinion in the first Hughes case, stated he had no difficulty with the shingle theory.

${ }^{157}$ Supra note 148 .

${ }^{158}$ Clauses $(x)$ and (2) of $\S 206$, the anti-fraud provision of the Investment Advisers Act " of" 1940 , 54 Stat. 852 ( 1940$)$, $x_{5}$ U.S.C. $\$ 80 \mathrm{~b}-6$ ( 1958$)$, are similar to clauses $(x)$ and $(3)$ of $\$ I 7(a)$ of the Securities Act. Clause (4) of $\$ 206$, a 1960 amendment, 74 Stat. 887 , resembles $\S 15(c)(2)$ of the 
adviser had engaged in the practice of buying shares of stock shortly before advising the subscribers to its advisory service to buy the stock for long-term investment, and selling its shares at a profit shortly after publishing and transmitting its recommendations to subscribers. This practice is known in the industry as "scalping" and is designed to take advantage of the temporary market effect of a "buy" recommendation by an advisory service whose recommendations are widely disseminated. ${ }^{100}$ The Commission, taking the position that such practice was a violation of the adviser's fiduciary duty to his clients, sought to enjoin the distribution of the advisory service containing the recommendations unless this practice was disclosed. The district court and court of appeals denied the Commission's request on the ground that such a practice was not prohibited by the anti-fraud provision of the Investment Advisers Act. ${ }^{160}$ The Supreme Court, however, found that the lower courts had interpreted the provision in a technical and narrow common law sense, and reversed their decisions on the ground that the practices operated "as a fraud and deceit" under the broad remedial interpretation to which the statute was entitled.

In coming to this conclusion the Court based much of its reasoning on the congressional report leading to passage of the Investment Advisers Act, but also referred to the conditions which preceded the 1933 and 1934 acts. ${ }^{101}$ The Court noted that the Investment Advisers Act was the last of the statutes, dealing with the securities industry, enacted after disclosure of the abuses which had occurred in the rgzos. Following the decision in the first Hughes case, the Court stated that a fundamental purpose common to these statutes was "to substitute a philosophy of full disclosure for the philosophy of caveat emptor and thus to achieve a high standard of business ethics in the securities industry," ${ }^{102}$ and that Congress intended the Investment Advisers Act to be construed "like other securities legislation 'enacted for the purpose of avoiding frauds' not technically and restrictively, but rather flexibly to effectuate its remedial purposes." ${ }^{\text {163 }}$ Thus, the omission of a provision similar to one contained in the Securities Act making failure to disclose material facts unlawful was not found to be controlling; instead the Court relied on the general proscription against

Exchange Act, and grants the Commission specific rule-making power to define and prevent fraudulent, deceptive, or manipulative practices. The specific issue involved in the Capital Gains case was whether the adviser's practice violated clause (2) of $\$ 206$. That clause made it unlawful for an investment adviser "to engage in any transaction, practice, or course of business which operates as a fraud or deceit upon any client or prospective client" by the jurisdictional means.

${ }^{150}$ The Commission based the request for the injunction on six instances in which the investment adviser had followed this practice and one instance in which the firm sold a security "short," recommended that its clients sell the security, and then bought the security to cover its short sale at the lower price after the recommendation was published. See the Appendix to the Court's opinion. 375 U.S. at 202.

${ }^{100} 19 \mathrm{r}$ F. Supp. 897 (S.D.N.Y. 196x), 300 F.2d 745 (2d Cir. 196r), affd on rehearing en bane, 306 F.2d 606 (2d Cir. 1962).

${ }_{161} 375$ U.S. at 186.

202 lbid.

${ }^{100}$ Id. at 195. 
fraudulent and deceptive practices contained in the act. It found the content of this proscription in the modern, equitable concept of fraud which courts were applying to commercial transactions at the time the Investment Advisers Act was passed. The decision expressly rejected the view of the lower courts that the Commission would have to rely on the rule-making power granted to it in the statute to prevent scalping rather than on interpretation of the general anti-fraud provision. ${ }^{104}$

Court review of Commission action in this area has performed the function, noted by Judge Friendly, of causing "an agency to focus on the issues more closely and to define its standards more sharply."165 This was shown in the recent series of Commission and court decisions involving the broker-dealer firm of Mac Robbins \& Co. In its first opinion, the Commission found that the firm had sold securities by fraudulent means and that nine of the firm's salesmen had participated in such activities and were "causes" of the revocation of the firm's registration, ${ }^{166}$ thus precluding their employment by any other registered broker-dealer or NASD member, without prior Commission or NASD approval. Two of the salesmen appealed from this administrative action. In oral argument before the Court of Appeals for the Second Circuit, the Commission indicated that, although its opinion did not expressly reflect this view, its decision was based on the fact that the broker-dealer had been conducting a boiler room, and that appellants had participated in its operation. As the Supreme Court did in the first Chenery case, ${ }^{167}$ the court remanded the cases to the Commission to make its theory of law clearer, and to respond to a series of questions in light of its administrative expertise. ${ }^{168}$ Among the questions put by the court were: (I) whether the Commission in its discussion of the use of the firm's fraudulent sales materials by the salesmen intended to develop a universal rule for sales conduct (whether or not part of a boiler-room operation); (2) whether participation in a boiler-room operation affected the scope of a salesman's responsibilities; and (3) whether, in sales presentations, salesmen could rely on information furnished by their employer. In its second opinion the Commission indicated that it had not intended to articulate a rule covering salesmen in all contexts. ${ }^{169}$ It found, however, that in the case under consideration the salesmen were integral parts of the boilerroom operation and should have known of the fraudulent character of the sales literature the firm was using. In such a situation, it was stated, a salesman cannot rely on materials furnished to him by his employer without a careful investigation of their accuracy, particularly where there were adequate warning signs in the literature. The Commission specifically based its decision on the duty of fair dealing required of broker-dealers and their salesmen under the shingle theory. Upon

104 Id. at 198.

${ }^{100}$ FriendLY I4I.

${ }^{100}$ Mac Robbins \& Co., 40 S.E.C. 497 (I96I).

107 SEC v. Chenery Corp., 318 U.S. 80 (1943).

${ }^{108} \mathrm{Kahn}$ v. SEC, 297 F.2d Ir2 (2d Cir. 196r); Berko v. SEC, 297 F.2d r16 (2d Cir. 196r). While the analogy is not precise, the purpose and effect of the remand was the same in both situations.

101 Mac Robbins \& Co., SEC Securities Exchange Act Release No. 6846, at 12 (July II, 1962). 
appeal, the court upheld this rule as a reasonable interpretation of the Exchange Act as a remedial statute..$^{170}$

\section{Comment on the Commission's Use of Rules, Cases, and Statements of Policy}

The different techniques employed by the Commission to develop standards illustrate some of their merits and disadvantages. Formal rules can take the form of flat prohibitions or disclosure requirements, or they can prescribe other preventive means which could not have been as quickly or comprehensively developed by the process of adjudication. They can be used to set guidelines for very complex matters such as stabilization transactions. However, the rules in these complex areas tend to be involved, and as fresh experience is acquired and abuses develop further interpretation, either informally or in administrative proceedings, may be required. A major problem recognized by courts is that very specific rules may permit unethical persons to devise schemes to avoid them. ${ }^{171}$ For this reason the Commission has promulgated rules prescribing a general standard of conduct which can be interpreted and applied to particular practices or courses of conduct in administrative proceedings, as well as specific rules dealing with relatively uncommon practices.

Because of the unlimited variety of opportunities for unethical practices presented in sales transactions, the Commission has relied heavily upon adjudication in the development of standards for selling practices. The emphasis on the factual context in administrative proceedings has provided a definite advantage in resolving the issues and the policy considerations present in determining whether particular conduct violated the anti-fraud provisions. In the early cases, the Commission used broader language to describe the duty required of broker-dealers toward their customers than may have been necessary to dispose of the particular issue before it. The excessive price or secret profit cases are good examples. They provided the background against which the Commission developed the shingle and fiduciary theories and formed a basis for later development of other important selling practice standards. Of equal importance is the flexibility afforded by the case method because of the discretion it offers in terms of application of the principle announced in a particular case and the opportunity for further refinement or modification in later cases.

The problems which would flow from the loss of this flexibility if agencies were limited to formal rule-making powers in the development of standards are illustrated by the Commission's efforts to curb boiler-room operations. Although the proposed boiler-room rule was given thorough consideration by the Commission and staff before it was released for public comment, the Commission has refrained from

${ }^{170}$ Berko v. SEC, supra note 149 .

171 "Fraud is infinite, and were a Court of Equity to once lay down rules, how far they Would go, and no farther, in extending their relief against it, or to define strictly the species or evidence of it, the jurisdiction would be cramped, and perpetually eluded by new schemes which the fertility of man's invention would contrive." Letter of Lord Hardwicke to Lord Kames dated June 30, I759, cited in the Capital Gains decision, 375 U.S. at 193 n.4. 
declaring the rule effective. In contrast, the decisions in the proceedings concerning boiler rooms have articulated standards of conduct for broker-dealers and have greatly aided the Commission's efforts to put such firms and their salesmen out of business. And, as indicated, they achieve this without the claimed disadvantages of the proposed formal rule.

Another example of the flexibility provided by adjudication, as well as of the importance of the factual context provided by cases, is the principle which the Commission enunciated in Cady, Roberts \& Co. ${ }^{172}$ That case broadly concerned the duties of all persons possessing non-public information as a result of a special relationship with an issuer of securities, but it dealt specifically with the duties of a broker-dealer in possession of such information. In earlier cases, the Commission had indicated that a broker-dealer who is purchasing securities for an insider and knows that the insider possesses non-public information has a duty to disclose the information to the seller or disassociate himself from the transaction, ${ }^{\mathbf{1 7 3}}$ and also that sales by a broker-dealer by means of representations which he knew to be misleading because of confidential information received from an issuer violated the anti-fraud provisions. ${ }^{174}$ In Cady, Roberts, the broker had executed sales on an exchange for his discretionary accounts because of his knowledge of a dividend reduction, not yet publicly announced, which he received from a director of the corporation who was an employee of his brokerage firm. The Commission held that, because of the broker's special access to corporate information and the unfairness of executing such sales before the information became public, these sales violated the anti-fraud provisions. The broker could only have avoided the violations by disclosing the information before effecting the transactions, or, if that were impracticable, by foregoing the transaction. Under the circumstances presented, the Commission indicated that the proper course would have been to forego the transactions until news of the dividend reduction had been made public. ${ }^{175}$

The Commission rejected respondents' argument that the action was compelled by the fiduciary duty which was owed to owners of the discretionary accounts. This case has significance because it applies the high standards required of corporate insiders, i.e., officers, directors and controlling stockholders, to a broker-dealer who was not an insider but received information from an insider with whom he was associated, and because it applies to sales on an exchange where the broker-dealer makes no representations and, in fact, has no actual contact with the purchaser. There is, at least, reasonable question whether the Commission would have promulgated a general formal rule embodying the standard of conduct enunciated in this case without an actual situation involving improper conduct before it and without the benefit of having the competing arguments of law and policy which are frequently most sharply drawn in adjudicatory proceedings. Furthermore, there would

${ }^{172} 40$ S.E.C. 907 ( $\left.196 \mathrm{I}\right)$.

${ }^{173}$ Hughes \& Treat, 22 S.E.C. 623,626 (1946).

${ }^{174}$ Van Alstyne, Noel \& Co., 33 S.E.C. 3 Ir, 32I (1952)...

${ }^{778} 40$ S.E.C. 907 , at 915 . 
seem to be little point in attempting to draft a series of rules having only a specific and limited application, particularly since it would be virtually impossible to reach the myriad situations which could arise. Removal of the adjudication power from the Commission could thus hinder or preclude the opportunity for, the development of such a rule as well as deny the Commission the insight which the adjudication of cases provides to it in connection with all of its regulatory activities, whether formal or informal.

The flexibility provided by adjudication so necessary for the development of selling practice standards has not been of equal importance in other areas of Commission responsibility. For example, as another paper in this symposium indicates, ${ }^{170}$ the Commission has relied on detailed formal rules and informal procedures to perform the task of regulation of proxy solicitations assigned to it. It has utilized a similar approach in developing and announcing policies as to disclosures required in new offerings of securities under the Securities $\mathrm{Act}^{177}$ and in connection with registration for trading on the exchanges. ${ }^{178}$ Because of the great number of registration statements, annual and other reports, applications, sales literature, and proxy statements which the Commission reviews each year and the necessity for expeditious treatment, particularly in the case of proxy solicitations and new issues of securities, it would be impracticable to use formal administrative proceedings as a regular means to process them even though the statutes seem to provide expressly for such proceedings to test their accuracy and adequacy. ${ }^{179}$ Furthermore, these materials only infrequently raise questions of fraudulent conduct comparable to that found in the sales practice area. The Commission developed, at the beginning of its administration of these provisions, informal procedures which provide an effective and efficient means of assuring statutory compliance. These procedures and the Commission's willingness to provide informal interpretative and other assistance to those affected by the statutes have been the subject of favorable comment. ${ }^{180}$ The Commission has attempted to match the administrative device to the statutory objective in developing relevant policies concerning regulated activities.

Adjudication also seems to provide an advantage for the enunciation of policies because of the different reactions by interested persons and the Bar to a policy stated in a case and to one enunciated in a formal rule. When an agency publishes a proposed rule for comment there is a tendency to evaluate it in terms of the maximum possible scope of its language. Objectors envision highly unusual factual situations which might conceivably fall within the literal wording of the rule. The creators of these ingenious hypothetical cases find little comfort in the obvious answer - that no sensible administrator, and certainly no reviewing court, would interpret ${ }^{270}$ Von Mehren \& McCarroll, The Proxy Rules: A Case Study in the Administrative Process, 29 LAW \& CONTEMP. Prob. 728 (1964).

${ }^{177}$ I Loss $272-77$.

1782 Loss $792-95$.

170 Securities Act $\$ 8$; Exchange Act $\$ 19$ (a)(2).

180 Task Force Report on Legal Services and Procedures, Comaission on Organtzation of thte Executrve Braxch 189, I9x (1955); Report of the Attorney General's Committee on Administrative Procedure, S. Doc. No. 8, 77th Cong., Ist Sess. 39 (I94I). 
the rule to cover such extreme cases. By contrast, a statement in an adjudicatory opinion is evaluated against the specific factual context. There is a general understanding that the precedential value of an opinion is limited by the underlying facts. Though an opinion foreshadows future developments, there is an awareness that its dictum will not be applied literally in every conceivable circumstance.

Without losing the advantages of adjudication in developing new standards, agencies can obtain certain other benefits by codifying in formal rules or public statements standards already established in administrative proceedings. This can serve to resolve any minor inconsistencies and also to provide a single readily available source for those seeking to ascertain agency policy. The Commission has done this for broker-dealer selling practice standards to some degree by the statements on the duties of broker-dealers selling unregistered securities ${ }^{181}$ and the problems involved in the distribution of "hot issues."182

Such codification has occurred to a greater extent under the Securities Act. Probably the most important rules under that statute are those defining the terms used in sections $2,3,4$, and 5 of the statute which determine the types of securities and transactions to which the registration requirements of the act apply. A number of proceedings involving these provisions have led to the development of new rules or the modification of existing ones. Examples are rule 133 which embodies the principle that "no sale" is involved in statutory mergers and acquisitions, ${ }^{183}$ rule I55 concerning the non-public sale and subsequent distribution of convertible securities or the securities underlying them, ${ }^{184}$ and rule 154 which relates to the exemption from registration for ordinary brokerage transactions. ${ }^{185}$

A number of reasons may be assigned for the restatement of these policies under the 1933 Act in formal rules after considering them in adjudicatory proceedings. Probably most important is the need for certainty in transactions to which the Securities Act may apply, which often involve many millions of dollars and a variety of persons, issuers, underwriters, dealers and their counsel and accountants. The act imposes what amounts almost to an absolute civil liability on an issuer and persons participating in an illegal distribution of securities. Because of the Commission's practice of furnishing administrative interpretations with respect to the necessity of registering securities, there is a strong inducement to insure equal treatment and to reduce staff workload by articulating these standards as precisely as possible and publishing them widely in the form of rules. On the other hand, the variety of selling efforts and the need for flexibility to prevent technical avoidance make rules fixing standards in this area less suitable for articulation in formal rules than standards for determining which transactions require registration under

${ }^{181}$ SEC Securities Act Release No. 4445 and Securities Exchange Act Release No. 672I (Feb. 2, 1962).

${ }^{162}$ SEC Securities Exchange Act Release No. 6097 (Oct. 23, 1959).

${ }^{183}$ See Great Sweet Grass Oils, Ltd. 37 S.E.C. 683 (1957); I Loss 528-39.

${ }^{184}$ See Crowell-Collier Publishing Co., SEC Securities Act Release No. 3825 (Aug. 12, 1957); I Loss $665-86$

${ }^{185}$ Ira Haupt \& Co., 23 S.E.C. 589 (I946); I Loss 700-o6. 
the Securities Act. Moreover, the tendency, already noticed, for the self-regulatory organizations to codify these standards and the guidance they offer to their memberships decrease the need to articulate the selling practice policies as precisely as those concerning registration of securities. Despite these differences, additional case developed selling practice standards may be appropriate for codification by formal rule or statement of policy when the Commission has had sufficient experience with them.

Public statements are subject to some limitations as tools for policy development. The very essence of the administrative process is that only through constant exposure and cumulative experience can the agency develop and formulate appropriate policy. As problems arise, an agency must make policy determinations promptly not only to meet its statutory responsibilities, but also to guide those affected. Many of these policy determinations involve unique fact situations or otherwise have limited application. Others may represent initial reactions to emerging problems of greater significance. It would be unwise to publish such informal administrative policy interpretations before they are adequately tested. Not only would there be loss of administrative flexibility, but premature publication of policies derived from limited experience might lead to confusion and retard modification suggested by greater experience. On the other hand, when experience permits enunciation and publication of thoroughly considered policy determinations, there seems to be little difference between a statement of policy and a formal rule. In fact, statements of policy may have the disadvantage of not having the legal effect of a rule should the Commission later attempt to take administrative or court action for violation of the policies reflected in the statement. And, persons who rely upon Commission rules are provided certain statutory protection, if the rule is later changed or invalidated, not afforded those who rely on statements of policy. ${ }^{186}$

The functions for which statements of policy seem best suited are as warnings or as explanations of how the agency intends to deal with specific fact situations or of certain informal administrative procedures. An example of a statement of policy serving as a warning device under the Securities Act is the Commission's "Canadian Restricted List." This list, which is periodically brought up to date, indicates the Canadian issuers of securities which the Commission believes are being distributed in this country in violation of the securities registration requirements, and thus alerts broker-dealers to the fact that they may be violating the act by participating in illegal distributions if they execute customers' orders for these securities. ${ }^{187}$ An example of a statement designed to publicize informal procedures is the release recently pub-

${ }^{188}$ Securities Act $\$ I 9(2)$; Securities Exchange Act $\$ 23$ (a). As a practical matter, the Commission does not take action against a party who has relied on a written or oral interpretation made by a member of the staff.

${ }^{187}$ From I95I until 1956 , the list was distributed by the NASD, but since then the Commission has published it as a release under the Securities Act. SEC Securities Act Release No. 3632 (April 24, 1956). The latest version of the list was published on May 8, 1964. SEC Securities Act Release No. 4689. The use of the Canadian Restricted List as a warning device for broker-dealers has been upheld by the courts. Kukatush Mining Corp. v. SEC, 309 F.2d 647 (D.C. Cir. 1962). 
lished by the Commission describing certain established administrative practices which the staff follows in the processing of registration statements under the Securities Act of $1933 .{ }^{188}$ Although the publication of this release was intended as an aid to issuers and their counsel and to insure uniform staff treatment of registration statements, this effort has not been universally acclaimed..$^{189}$

\section{Criticism of the Combrnation of Adjudication and \\ Other Functions in One Agency}

Closely related to the charge that the agencies have failed to develop adequate standards is the criticism of the combination in one agency of adjudication with enforcement, policy-making and planning functions. Earlier criticism was based on the view that the exercise of these functions by one body violated the principle that the same man or group should not be both prosecutor and judge. ${ }^{190}$ More recent criticism is based on the conclusion that the time and effort involved in deciding individual cases interfere with the agencies main task of developing and enforcing specific policies under general statutory mandates. ${ }^{101}$ This may be another way of expressing the view that adjudication is inefficient and inadequate for proper development of policies and standards. The solution most generally proposed to deal with the problems claimed to exist is that adjudication be separated from other agency functions, either by turning over these functions to the regular federal courts or to a special administrative court system somewhat similar to that found in Continental countries, or by keeping the adjudicatory function within the agency but setting up internal barriers between it and other activities in which the agency is engaged. ${ }^{192}$ The proposals for external separation are designed to avoid the alleged inefficiency of adjudication for policy development as well as to insure fairness; suggestions for internal separation are aimed primarily at the second of these goals.

Recent examples of proposals calling for external separation are the memorandum submitted to the President by Louis Hector on his resignation from the Civil Aeronautics Board in $1959^{193}$ and the letter sent to the President four years later by Newton Minow on his resignation as Chairman of the Federal Communications Commission (FCC). ${ }^{194} \mathrm{Mr}$. Hector contended that the combination of functions

${ }^{188}$ SEC Securities Act Release No. 4666 (Feb. 7, 1964).

${ }^{280} \mathrm{~A}$ special committee of the Association of the Bar of the City of New York recently indicated that it felt that this release and another which the Commission recently published on Rule ${ }_{54} 4$ under the Securities Act, SEC Securities Act Release No. 4669 (Feb. 17, 1964), were attempts to make rules without observing procedural requirements of the Administrative Procedure Act. Other securities practitioners, however, have indicated that, although the releases may have defects, their publication is helpful. E.g., Israels, Notes and Views, N.Y. Law Journal, Mar. 26, 1964, p. I.

${ }^{200}$ See 2 DAvis $\$$ r3.or.

${ }^{101}$ Letter from Newton N. Minow to the President, May 3x, 1963 (available from the Federal Communications Commission); Hector, Problems of the CAB and the Independent Regulatory Commissions, 69 YALE L.J. 931, 933-35, 953-57 (1960).

${ }^{103}$ See 2 Davis $\$ 13.03$.

${ }^{103}$ Sulpra note I9I.

106 Supra note rgr. 
made the $C A B$ inefficient and that its adjudication procedures were unfair to the persons affected. He generalized from this that the policy-making, adjudicatory, administrative and investigative duties, which are vested in most independent agencies, were by their nature incompatible. Therefore, he proposed giving the agencies' policy-making and planning functions to new executive branch agencies, their adjudicatory functions to an administrative court, and the enforcement functions of investigation and prosecution to an executive department or agency which already performs such duties (for example, the Justice Department). Mr. Minow limited his remarks to the operations of the FCC, but agreed basically with Mr. Hector. However, he proposed splitting the FCC's activities between a single administrator and an administrative court instead of the three groups proposed by Mr. Hector. ${ }^{105}$ Despite their frequency over a period of about twenty-five years, proposals for complete severance of adjudication from other agency functions have been adopted, and then in modified form, for only one major agency, the National Labor Relations Board (NLRB). . $^{196}$

Unlike proposals for external separation, those for internal separation have had more acceptance. The proposals in this regard made by the majority of the Attorney General's Committee on Administrative Procedure in $194 \mathrm{I}^{\mathbf{1 0 7}}$ were substantially cmbodied in the Administrative Procedure Act when it was passed in $1946{ }^{108}$ The basic effect of the internal separation provision in section 5(c) of the Admnistrative Procedure Act is to insure that the decisional officers will not be persons involved in the investigation or prosecution of a case. ${ }^{109}$ It also prohibits consultation by the decisional officers with any party to the proceeding without notice and opportunity for all parties to participate.

\section{Commission's Internal Separation of Functions}

The Commission had a system of internal separation of functions to achieve fairness and impartiality in adjudicatory proceedings before enactment of the Administrative Procedure Act. ${ }^{200}$ Thus, only minor changes and refinements were made when the act was passed.

When testimony and other evidence must be taken, as is the case in all con-

${ }^{105}$ Since this article is primarily concerned with the operations of an agency which exercises adjudicatory functions, no effort is made to discuss the merits of the different forms proposed for establishing external separation of functions.

${ }^{100} 2$ DavIs $\$$ 13.04. Congress has also increased the extent of the separation of functions required for the FCC, although not going as far as it did with the NLRB. lbid.

${ }^{197}$ Report of Attorney General's Committee on Administrative Procedure, supra note 180, at 55-60.

${ }^{198} 60$ Stat. $237-44$ (1946), 5 U.S.C. $\$$ roor-II (1958). A study completed shortly after the release of the report of the Attorney General's Committee indicated that many agencies had already adopted a substantial separation of functions for the purpose of achieving impartiality in thcir actions. Nathanson, Separation of Functions Within Federal Administrative Agencies, 35 ILx. L. Rev. 901 (1941). One legal historian believes that such separation in the larger agencies was also the natural result of the growth of business and the need for division of labor. Willard Hurst, The Growtil of Amenucan LAw 430 ( 1950 ).

${ }^{200}$ Agency members, i.e., Commissioners, are exempt from this prohibition. Scc p. 722 infra.

${ }^{200}$ Nathanson, supra note 198, at 92I-24. 
tested broker-dealer revocation or denial proceedings, hearings are held before a hearing officer who is completely independent of the staff members who investigated the matter or who are participating in the proceedings. This officer is not allowed to confer ex parte about any of the facts in issue in the proceeding with Commission counsel, or any others, participating in the case. The investigation which precedes initiation of adjudicatory proceedings is conducted, and the charges in the proceedings are prosecuted, by the division of the Commission having enforcement or regulatory responsibility for such matters. Hearings in broker-dealer proceedings are usually held in the locality where the alleged violations occurred and are conducted by the personnel of the particular regional office of the Commission for that geographical area in conjunction with the Division of Trading and Markets, which has the primary responsibility for broker-dealer regulation. The Commission's permanent staff of hearing officers, known as hearing examiners, is assigned to the executive staff of the Commission. They are not subject to the supervision of any employee engaged in the performance of investigative or prosecutive functions. Staff members involved in the proceedings may not participate in the drafting of a decision by the hearing examiner and, if a decision by him is waived by the parties, such staff members may not assist the Commission in the preparation of its decision unless the parties agree to their participation. In noncontested broker-dealer proceedings in which the facts have been stipulated, the respondents often agree to such participation in the decisional process to expedite disposition of the case.

In addition to the hearing examiners, the Commission has an independent decisional division, the Office of Opinions and Review (formerly the Office of Opinion Writing). As its title suggests, the primary responsibility of this office is the drafting of final opinions under the instructions of the Commission, either after hearing and decision by the hearing examiner or de novo when such procedures have been waived. Opinions and Review personnel are under the same restrictions as are hearing examiners, so far as discussion of issues of a case are concerned.

A question concerning agency separation of functions is whether an allegation of a violation of the separation of function requirement permits court review of the administrative proceedings before they have been completed. Three recent decisions by the United States Court of Appeals for the District of Columbia illustrate some of the underlying issues involved in answering this question. These decisions all involved the Commission, but have significance for all agencies subject to the Administrative Procedure Act.

In the first decision, R. A. Holman \& Co.v. SEC, ${ }^{201}$ the court upheld the refusal of the district court to enjoin broker-dealer revocation proceedings because the alleged procedural irregularities-lack of a quorum and ex parte communications between the Commission and the staff-were not of such a fundamental nature that the court would interfere at that stage of the proceedings. The court stated that the Commission should be given the opportunity to correct the irregularities if any existed. The

${ }^{201} 299$ F.2d I27 (D.C. Cir. I962), cert. denied, 370 U.S. $9 x$ I (1962). 
court also pointed out that, in any event, these allegations might not prove to be reversible error upon appeal after the administrative proceedings were completed.

Shortly thereafter, the same court of appeals reached a different result in a similar case in which the senior author was somewhat painfully involved, Amos Treat \& Co. v. SEC. ${ }^{202}$ Plaintiff sought an injunction against continuance of a brokerdealer revocation proceeding on the ground that the author's participation in the consideration of the case as a member of the Commission violated due process of law and section 5(c) of the Administrative Procedure Act because he had previously served as director of a division of the staff which had been involved in an investigation of a factually-related proceeding. ${ }^{203}$ On appeal from the district court's dismissal of the complaint, the Commission argued first that the questions raised by plaintiff should be determined on an appeal from the Commission's final order in the proceedings, but also that the author's participation did not violate due process and that he was exempted from the operation of section 5 (c) by its last clause which provides that it does not apply "in any manner to the agency or any member or members of the body comprising the agency."204 The court, however, went directly to the merits of plaintiff's contentions and interpreted section 5 (c) only to permit an agency member to vote on initiation of an investigation or proceeding and still adjudicate the matter when it reached the decision stage. The court ordered, "solely on due process grounds," that an injunction issue and that it be made permanent unless the proceedings were terminated or the Commission held a full evidentiary hearing on the question whether the author should have been disqualified because of prior staff participation in the case. ${ }^{205}$

In a second decision involving $\mathrm{R}$. A. Holman \& Co., plaintiff made the same charges as in the Treat case, but in this case the court denied the injunction. ${ }^{200}$ The court held that the decision in the Treat case rested on the record established there and that was an "exceptional" case. Here, the allegation that another Commissioner had actively participated in the investigation as a division director was formally denied by the Commission, whereas in the Treat case the Commission had moved to dismiss the complaint without formally answering the allegations. In this case, the court held that plaintiff would first have to exhaust all of its administrative remedies, before raising a question of violation of due process. The court recognized that to do otherwise would greatly hinder the efficiency of the administrative process by making it subject to many delays by persons against whom 202306 F.2d 260 (D.C. Cir. 1962).

208 Petitioners expressly disclaimed charging the author with personal bias or prejudice and indicated that their request was based on the fact that as the director of the division he had been responsible for all of its activities, including the investigation of the factually related matter. 306 F.2d at 265.

201 The Commission also argued that the issue of the author's participation was moot because he had disqualified himself from further consideration of the proceedings.

${ }^{205}$ If the first of these alternatives were chosen, the Commission was expressly permitted to reinstitute the proceedings, so long as the author did not participate further, and that is what was done.

${ }^{208}$ R. A. Holman \& Co. v. SEC, 323 F.2d 284 (D.C. Cir. 1963 ), cert. denied, 375 U.S. 943 (1963). 
proceedings might be taken. ${ }^{207}$ The problems implicit in these decisions will undoubtedly receive further consideration. ${ }^{208}$

\section{Delegation of Adjudication Functions}

The Commission has recently taken certain actions in regard to the conduct of its administrative proceedings which should improve the efficiency of adjudication as a tool for policy development within its system of internal separation of functions. As indicated earlier, the modern advocates of external separation of functions believe that is necessary to free agencies from routine adjudication so that they will have more time to devote to policy making. Although, as shown, adjudication is a valuable, indeed a necessary, tool for policy making, it must be admitted that many administrative proceedings are routine and do not present difficult or important questions. Therefore, the prime concern of the agency is to insure that the statutory and administrative standards are applied fairly. Both aims can be achieved by a careful system of delegating decisional authority within the agency. The Administrative Procedure Act authorizes this by allowing agencies either to adopt an "initial" decision procedure, whereby the decision of the hearing officer becomes final unless it is appealed to the agency or the agency reviews the case on its own motion, or a "recommended" decision procedure, whereby the decision of the hearing officer is only advisory and the agency must consider the case and promulgate its own order. ${ }^{209}$ Apart from this, specific authority to delegate the power to decide cases, within certain limitations, was granted to the Commission in $1962 .{ }^{210}$

Traditionally, the Commission has employed the recommended decision procedure. This course was viewed as necessary in light of the large number of important policy questions involved in adjudicatory proceedings under most of the statutes which the Commission administers. And, in proceedings under the Public Utility Holding Company Act of 1935 and the Investment Company Act of r940, many of which technically are rule-making under the Administrative Procedure Act, the parties frequently sought a Commission decision as promptly as possible. In these circumstances, an initial decision by a hearing examiner might serve only to prolong proceedings without significantly aiding in their disposition.

The Commission has a corps of experienced and competent hearing examiners. Many major policy questions under the statutes have been solved and guidelines as to others have been enunciated and refined. In consequence, the Commission has recently proposed that an initial decision procedure take the place of the recommended decision procedure. ${ }^{211}$ Under the proposed rule changes, initial decisions

${ }^{207} 323$ F.2d at 287 .

${ }^{308}$ Law, Disqualification of SEC Commissioners Appointed From the Staff: Amos Treat, R. A. Holman, and the Threat to Expertise, 49 CORNell L.Q. 257 (1964); 64 CoLuM. L. Rev. 785 (I964).

${ }^{200}$ Administrative Procedure Act $\S(8)(a), 60$ Stat. 242 (1946), 5 U.S.C. $\$ 1007$ (a) (1954).

91076 Stat. 394 (1962), 15 U.S.C. $\$ 78 \mathrm{~d}-1$ (Supp. IV, 1963).

211 SEC Securities Act Release No. 4687 (May I, I964). 
will be issued in any administrative proceeding in which a hearing officer is used under all of the statutes administered by the Commission.

Under the Administrative Procedure Act, agencies have the power to "limit the issues upon notice or by rule" when review of an initial decision procedure is sought. ${ }^{212}$ The Commission has had a rule requiring that an exception to a hearing examiner's decision be briefed or the exception will be deemed to have been waived. ${ }^{213}$ The proposed initial decision procedure also provides that the person appealing from the hearing examiner's decision must establish that the decision includes either a finding of fact or law which is clearly erroneous or some other important determination which the agency should review; otherwise, the Commission may deny the petition for review or summarily affirm the hearing examiner's decision.14 Whether or not a petition for review is filed, the Commission will be able to bring decisions up for review on its own motion when it feels that is necessary or appropriate.

Decisional authority in other respects has been delegated to reduce the number of routine matters requiring Commission attention. The Commission has always followed an extremely liberal policy of considering appeals from rulings by hearing examiners on interlocutory motions during the administrative proceedings, a policy which encouraged dilatory maneuvers by some respondents. Recently, the Commission changed its rules of practice to reduce the number of interlocutory appeals which it will consider. Power has been delegated to the Office of Opinions and Review to affirm the refusal by hearing examiners to certify to the Commission rulings on these motions or to affirm the hearing examiners' rulings on motions when the hearing examiners do certify them to the Commission. ${ }^{215}$ On matters that do not fall within settled precedent or where the decision may otherwise be significant, the director of that office will bring the matter to the Commission for determination.

In connection with certain administrative proceedings, including those relating to broker-dealer registration, the Commission has delegated to the Office of Opinions and Review the power to issue the final order taking the remedial action described in the order for proceedings when the parties have consented to such action, failed to appear, or failed to file required answers in such proceedings. ${ }^{210}$ The 1962 delegation of functions statute has also made it possible for the Commission to delegate many routine matters in non-adjudicatory areas and thus to devote more time to policy consideration in all its regulatory activities including significant administrative proceèdings. ${ }^{217}$

212 Administrative Procedure Act $\$ 8(\mathrm{a})$, supra note 209. Sce Attorney General's Manual on thie Administrative Procedure Act 84 (1947).

21s.SEC Rule of Practice I7(a), I7 C.F.R. $\$ 201.17(a)$ (1963).

214 Clause (d). of proposed Rule of Practice I7, supra note 211 , at vi-vii.

${ }^{218}$ SEC. Securities Act Release No. ${ }^{6} 64$ (Mar. 5, 1964).

${ }^{210}$ SEC Securities Act Release No. 4684 (April 8, 1964).

${ }^{217}$ SEC Securities Act Release No. 4588 (Mar, 8, 1963). 


\section{Conclusions}

Through formal rule-making, adjudication, and the use of statements of policy, the Commission has developed and enunciated a code of selling practice standards under the anti-fraud provisions of the securities acts. Each of the three procedures has been valuable in performing this task; adjudication seems to have been particularly appropriate and extremely important primarily because of the flexibility it provides. ${ }^{218}$ Adjudication has made it possible for the Commission to develop policies by moving gradually from problem to problem and to consider the: effect of prior decisions. Such an evolutionary development makes possible the further testing of policy against the background of live situations rather than imagined possibilities.

At the same time, the Commission has maintained internal separation of functions, as required by the Administrative Procedure Act to insure impartiality in adjudicative proceedings. Although the Holman and Treat cases indicate that all of the issues in that area are not resolved, the problem presented by those cases should not prove to be a major obstacle to efficient administrative action. While maintaining internal separation of functions, the Commission has taken steps to improve the efficiency of adjudication as a tool for policy making as well as to provide more time for developing policy by the other means available to it.

Our discussion was intended to illustrate the value of adjudication as a means of developing standards in appropriate situations. However, although it cannot be precisely measured, the experience and the expertise derived from the adjudication of formal proceedings has greatly benefited the Commission in all areas of the Commission's regulatory activities, including formal rule making. The adjudication of cases provides a feedback process for evaluating previously developed policies as well as a means of giving the Commission a factual basis for deciding what new policies are required by the changes constantly taking place in the industry. On the other hand, the knowledge of the operation of the securities industry gained from the Commission's constant informal regulatory activities results in better understanding of the real issues involved in the formal administrative proceedings which the Commission decides. Thus external separation of adjudication of cases from other regulatory activities would result in creating a regulatory agency and adjudicatory body, each of which would be less knowledgeable than an agency responsible for both activities. This conclusion seems especially apt in the case of an agency, such as the Commission which performs a great many of its regulatory functions on an informal basis.

The Commission's efforts in the selling practice area suggest the complexities involved in performing but one of the tasks assigned to a rather small agency, and they point up the weaknesses of proposals for improving the administrative process

${ }^{218}$ See Massel, The Regulatory Process, 26 LAw \& Contemp. Prob. I8I, I88 (I96r). 
by single concept or universal solutions such as complete external separation of functions. As one commentator has stated, agencies are "government in small," possessing all or many of government's powers in the regulated area and plagued by all or many of the problems faced by comprehensive governmental action. ${ }^{219}$

A major error in certain of the recent criticisms of the administrative process is the failure to recognize the limits of governmental action in regulating a segment of the economy, especially when that regulation is subject to the proper limitations which are imposed on it in a constitutional democracy such as ours. The criticism also ignores the problems in imposing an effective regulatory scheme on the rapidly changing technologies of regulated industries. Perhaps of more fundamental importance, some of the criticism and certain of the proposals ignore the basic ideas behind the creation of administrative agencies.

Professor Hurst, in his history of American legal institutions, lists four basic reasons for the creation of the specialized agencies: the desire for expertness in the particular area to be regulated; the conviction that a specialized agency could handle better the necessarily large volume of work by giving undivided attention to the administrative details involved; and the beliefs that agencies could develop policy and help Congress construct long-range programs, and, because of the circumstances of their creation, that they would enforce the policies of their enabling statutes in a vigorous manner. ${ }^{220}$ He believes that these reasons required an organization which, on the one hand, could keep in view the general policy of the statute and, on the other, could know what that policy meant in terms of individual application. In his view, these needs required a merger of legislative, executive, and judicial functions in a single body since separation of the judicial from the other functions would tend to make the agency more prosecution than policy-minded and would hinder the agency's main task-"the informal disposition of a great volume of matters without contest."221 Proposals which would impose uniform procedures on all administrative agencies and which would "judicialize" many types of informal proceedings ignore these reasons for the specialized agency and the character of much of its work.

The authors do not have any panaceas for the alleged ills of the administrative process, but believe that several of the proposals already made by others, particularly the proposal for a permanent Administrative Conference, offer real hope for improvement of agency operations. Unquestionably more can and should be done, as Judge Friendly urges, to define, to articulate, and to publish the standards of administrative action. The recruitment of able men at all levels of agency operation and their retention by the payment of adequate salaries are acknowledged necessities for effective agency performance. Constructive criticism is another essential requirement for agency improvement. Agencies and administrators are not intransigent

${ }^{910}$ Fick, Issues and Accomplishments in Administrative Regulation: Some Political Aspects, 26 LAw \& Contemp. Pros. 283,294 (xg6r).

220 Hurst, op. cit. supra note 198 , at $42 \mathrm{x}-23$.

292 Id. at 430 . 
when they can be shown that changes in procedure will result in improvement. Federal agencies have already implemented a great many of the recommendations of the I $961-62$ Administrative Conference. ${ }^{222}$ The Commission has benefited greatly from the evaluation and criticism of its performance by the Special Study of Securities Markets ${ }^{223}$ as well as from the important accomplishment of that group in studying and describing the changes which have taken place in the securities industry in the last thirty years. Studies of other industries and the agencies regulating them may be of similar benefit. The proposed permanent Administrative Conference will serve as a clearinghouse for the interchange of ideas among agency personnel, scholars of the law and government, and private persons. Since the primary and only goal of the Conference will be the improvement of the administrative process and its membership will include many knowledgeable persons from within and outside the government, its recommendations will not not be subject to criticism as reflecting the points of view of persons with special interests. Finally, considering the original reasons behind the creation of administrative agencies, experimentation in procedures and the organization of agencies should be encouraged. ${ }^{224}$

${ }^{222}$ As of Dec. 3I, 1962, the date on which the Conference concluded its business, agencies had already put into effect about $55 \%$ of the recommendations which could be carried out by administrative action and steps were under way or specifically proposed for another $20 \%$ of the recommendations. Memorandum of the Bureau of the Budget, June 13, 1963. We have been informed that many more recommendations have been put into effect since that time.

${ }^{223}$ Special Study, pt. 4, at 692-728.

${ }^{224}$ 'The proposal to create an official, similar to the Scandinavian "Ombudsman," who would have the responsibility of investigating complaints by private individuals of improper actions by departments and agencies of the government seems to offer attractive possibilities. Gellhorn, Administrative Procedure Reform: Hardy Perennial, 48 A.B.A.J. 243, 248 (I962); Davis, Ombudsmen in America: Officers to Criticize Administrative Action, I09 U. PA. L. REv. 1057 (196I). 